\title{
THE USE OF LONG ACTING SULFONAMIDES, ALONE OR WITH PYRIMETHAMINE. IN MALARIA (WITH SPECIAL REFERENCE TO SULFORMETOXINE)
}

\author{
J. Herrero **
}

The antimalarial activity of the sulfonamides was described very soon after the discovery of these drugs. As early as 1940, a number of papers, such as those by Diaz de León (31-33), Hill and Goodwin (56), Van der Wielen (129), Coggeshall (1820, 23), Niven (83), Chopra et al . (10-13), Menk and Mohr (81), Farinaud et al. (37-38), Sorley and Currie (118), Sinton et al. (117), etc., had reported on a somewhat variable success obtained with sulfonamides in experimental and human malaria. For a further 10 years, i.e. until 1950, there still existed some interest in this chemical group, as reflected in some important clinical trials, for instance those by Fairley et al. (36) and by Coatney et al. $(16,17)$. However, with the advent of more reliable synthetic antimalarials, chemotherapeutic work on sulfonamides with practical aims was almost dropped and rather remained limited to basic questions of more theoretical interest like mechanism of action, potentiation of the effect of other antimalarials of the folic-acid-antagonist group on experimental malaria, cross resistance, etc. This work is linked to renowned names such as Greenberg, Rollo, Goodwin, Bishop, Eyles and Coleman, Hitchings, etc.

Excellent cumulative reviews on sulfonamides and malaria have been made by Curd (27) in 1943, Findlay (42) in 1951, and Hill (58) in 1963.
It is somewhat astonishing that no major work was carried out during the years from 1955 to 1963 , i.e. during the period in which, thanks to the discovery of the so-called longacting sulfonamides, a better knowledge of the pharmacokinetics of these drugs was obtained. It is now evident that many of the early contradictory reports regarding the antimalarial effect of sulfonamides, made during the initial years of the sulfonamide era, were due to the scanty information on the pharmacokinetics of these substances in man and in laboratory animals, a gap which led or misled, among other things, towards empirical and therefore not quite reliable dosage.

At present, the reported resistance of certain Plasmodia strains to some major antimalarials such as pyrimethamine, chloroquine and perhaps even quinine, and, on the other hand, the availability of some sulfones and sulfonamides with a very sustained action, have made it advisable to reexamine the possible value of these substances as an auxiliary tool for the management of malaria. It is most unfortunate that this logical interest is hampered by the reports on cases of Stevens-Johnson and Lyell syndrome, observed during the use of some of these substances.

The purpose of this short review is to summarize: a) the available infor-

(*) Paper prestinted at the Round Table Conference on Malaria (Belo Horizonte, August 2, 1966) which followed the III International Pharmacological Congress in São Paulo (July 24-30, 1966) 
mation on the effect of the sulfonamides on the different species and cycle stages of Plasmodia, b) their mechanism of action and its implications, i.e.: potentiation and resistance, and c) the trials so far carried out with the longest acting sulfonamide sulformetoxine, Ro 4-4393*.

As it can be seen from Tables I to IV, the effect of the sulfonamides has been tested on the blood schizonts in most of the laboratory animal Plasmodia. They are considerably active against the blood schizonts of $P$. berghei, $P$. gallinaceum, $P$. knowlesi and $P$. falciparum and less or not active in the rest. The results obtained in cases of spontaneous or induced falciparum malaria have been almost unanimously positive although the onset of action of the sulfonamides is slower than that of the major antimalarials. This has precluded their use in the treatment of acute malaria. The results reported on malaria due to $P$. vivax are less uniform. Some authors find them to be effective here (although always less so than in $P$. falciparum), whereas others (35, $36,51,81,93,106)$ find practically no therapeutic activity. This may have been due to differences in the dosage or to the fact that the effects of different sulfonamides vary considerably (42). Very few investigations have been carried out with sulfonamides in cases of malariae and ovale malaria .

Sulfonamides have a definite causal prophylactic effect against certain Plasmodia such as $P$. knowlesi and $P$. gallinaceum (Table II) . Regarding human malaria, the reports are rather scanty, but it seems that sulfonamides, at the doses tested, do not act as causal prophylactics $(16,17)$.

The sulfonamides do not exert any effect on the gametocytes of the human types of malaria (Table III). In fact, they can even increase their number in the blood (41).

Fairley et al. in 1945 and Findlay et al. in 1946 reported that sulfame- zathine rendered the gametocytes of $P$. falciparum incapable of developing in the mosquito (Table IV). However, Laing in his recent studies did not find such an effect with Fanasil (70) . Further research on this subject is therefore needed. There is no information which would allow the assumption that sulfonamides possess any activity as secondary tissue schizonticides in human malaria. According to Bishop, exo-erythrocytic parasites are "relatively insensitive" to proguanil and sulfadiazine (7).

Mode of action of sulfonamides in malaria: It is paradoxical that the mechanism of action of sulfonamites, although not in all its details, is better known than that of most major antimalarials. Since the initial work by Maier and Riley (76), who proved in 1942 that the antimalarial effect of the sulfonamides is antagonized by $\mathrm{p}$ aminobenzoic acid, a number of studies have been carried out, mainly by Greenberg, Goodwin, Rollo, Bishop, Hitchings, Thurston, etc. (6, 47, 49, $50,59,60,101,102,127)$. Sulfonamides, biguanides and pyrimethamine constitute the group of the so-called folic-acid-antagonist antimalarials, $i$. e. "those antimalarials whose action has been considered to be concerned with interference with the syn. thesis of purines and pyrimidines via the $\mathrm{PAB} \rightarrow$ folic acid $\rightarrow$ folinic acid system" (102). According to Rollo (Fig. 1), sulfonamides probably act on reaction $A$ by simple metabolite competition, whereas biguanides and pyrimethamine act in a more complicated manner on reaction $B$. These analogies and differences between the mechanism of action of sulfonamides on the one hand and of the biguanides and pyrimethamine on the other entail a complex framework of possible reciprocal effects when two of these drugs are given together (potentiation) or in succession (cross resistance).

The possibility of cross resistance has been dealt with in several recent

(*) Trade name: Fanasil Roche (also mentioned in the literature as sulforthomidine and sulforthodimethoxine). 


\section{Blood schizonticidal activity}

Sulfonamides have been found active as blood schizonticldes in:

\begin{tabular}{|c|c|}
\hline Parasite & References \\
\hline P. berghei & $29,57-58,82,94,98-100,124-125$ \\
\hline P. gallinaceum & $28,58,78,94,119,132$ \\
\hline $\begin{array}{r}\text { P. lophurae (less sensitive than } \\
\text { P. gallinaceum) }\end{array}$ & $21,28,78,79$ \\
\hline $\begin{array}{c}\text { P. fallax (less sensitive than } \\
\text { P. gallinaceum) }\end{array}$ & 103 \\
\hline $\begin{array}{c}\text { P. circumflexum (less sensitive } \\
\text { than } P \text {. gallinacoum) }\end{array}$ & 77 \\
\hline P. knowlesi & $10-11,18-23,92,95$ \\
\hline $\begin{array}{c}\text { P. cynomolgi (less sensitive } \\
\text { than P. knowlesi }\end{array}$ & $21-23,53,116$ \\
\hline $\begin{array}{r}\text { P. inui (iess sensitive than } \\
\text { P. knowlesi) }\end{array}$ & $20,21,23$ \\
\hline P. falciparum & $\begin{array}{l}2,12-13,16,23,33,36-38,41,56, \\
66-69,71,73,75,81,83,89,106, \\
110,117,132\end{array}$ \\
\hline $\begin{array}{c}\text { P. vivax (less sensitive than } \\
\text { P. falciparum) }\end{array}$ & $\begin{array}{l}12-13,17,23,37-38,56,61,73, \\
118,132\end{array}$ \\
\hline $\begin{array}{l}\text { P. malariae (less sensitive } \\
\text { than P. falciparum) }\end{array}$ & $12-13,23,26,37,45,110,129,132$ \\
\hline
\end{tabular}

Sulfonamides have been found inactive as blood schizonticides in:

\begin{tabular}{|l|l|}
\hline \multicolumn{1}{|c|}{ Parasite } & \multicolumn{1}{|c|}{ References } \\
\hline P. lophurae & 18 \\
P. relictum & $27,29,57,77$ \\
P. cathemerium & $18,28,77,132$ \\
P. nucleophilum & 77 \\
P. vivax & $35-36,51,81,93,106$ \\
\hline
\end{tabular}

BEST CLASSICAL BLOOD SCHIZONTICIDAL DRUGS: 4-AMINOQUINOLINES MEPACRINE, QUININE, PYRIMETHAMINE, PROGUANIL OF THE ABOVE UNPRACTICAI FOR SUPPRESSION: MEPACRINE, QUININE UNPRACTICAL FOR TREATMENT: PYRIMETHAMINE, PROGUANIL 


\section{Table II}

\section{Causal prophylaxis}

Sulfonamides have been found active as causal prophylactics in:

\begin{tabular}{|l|l|}
\hline \multicolumn{1}{|c|}{ Parasite } & References \\
\hline $\begin{array}{l}\text { P. knowlesi } \\
\text { P. cynomolgi (less sensitive than } \\
\text { P. knowlesi) }\end{array}$ & 42 \\
P. gallinaceum & 53 \\
P. cathemerium* (canary) (less sensi- & 132 \\
tive than P. gallinaceum) & \\
P. lophurae (turkey) (less sensitive & 132 \\
P. falciparum than P. gallinaceum) & 117 \\
\hline
\end{tabular}

Sulfonamides have been found inactive as causal prophylactics in:

\begin{tabular}{|l|l|}
\hline \multicolumn{1}{|c|}{ Parasite } & References \\
\hline P. falciparum & $16,36,132$ \\
P. vivax & 16,36 \\
P. relictum & 77 \\
P. nucleophilum & 77 \\
P. cathemerium* (canary) & $18,28,132$ \\
P. lophurae (chicks and ducklings) & 18,28 \\
\hline
\end{tabular}

* Some sulfonamides active; some others inactive

BEST CLASSICAL CAUSAL PROPHYLACTIC DRUGS: PROGUANIL AND PYRIMETHAMINE (P. FAICIPARUM > P. VIVAX)

ACTIVE BUT NOT PRACTICAI: 8-AMINOQUINOLINES 
Table III

Gametocytocidal activity

Sulfonamides have been found inactive as gametocytocides in:

\begin{tabular}{|l|l|}
\hline \multicolumn{1}{|c|}{ Parasite } & \multicolumn{1}{|c|}{ References } \\
\hline P. falciparum & $14,33,36,42,70,111$ \\
P. vivax & 42 \\
P. malariae & 42 \\
\hline
\end{tabular}

\title{
BEST CLASSICAL GAMETOCYTOCIDAL DRUGS: 8-AMINOQUINOIINES
}

\section{ACTIVE ONLY IN P. VIVAX AND P. MAIARIAE: 4-AMINOQUINOIINES,}

\author{
MEPACRINE, QUININE
}

reviews $(7,58,107-109)$. Fig. 2 to 9 are a poor attempt to represent graphically the main observation of cross or coincidental resistance in experimental malaria due to Plasmodia berghei, gallinaceum, cynomolgi and knowlesi that have been reported. These figures make no claim to being complete or perfect since I may have missed some valuable reports. On the other hand, there are some minor discrepancies in the literature, undoubtedly due to differences in the techniques used for creating resistance and to the inevitable differences among the strains.

Nevertheless, with regard to any possible clinical application of sulfonamides (alone or combined with pyrimethamine) the most important facts about experimental cross resistance are:
1) Sulfonamide-resistant strains of some species of Plasmodia (e.g. $P$. gallinaceum) are usually also resistant to proguanil and pyrimethamine $(7,101)$.

2) Strains resistant to pyrimethamine and proguanil or its triazine derivative are generally not or only partially resistant to sulfonamides $(85,98,101,113,115$, 122, 126) .

3) DDS-resistant strains are usually resistant to sulfonamides $(8,87$ $88,90,122$ ).

4) Usually there is no cross resistance between sulfonamides or sulfones and antimalarials not belonging to the group of the folicacid-antagonists. Frequently there is even some hypersensitivity $(55,63,84-88,91,120,122)$. 


\section{Table IV}

\section{Sporontocidal activity}

Sulfonamides have been found active as sporontocidal drugs in:

\begin{tabular}{|c|c|}
\hline Parasite & References \\
\hline P. falciparum & 36,42 \\
\hline
\end{tabular}

Sulfonamides have been found inactive as sporontocidal drugs in:

\begin{tabular}{|c|c|}
\hline Parasite & References \\
\hline P. Palciparum & 70 \\
\hline
\end{tabular}

BEST CLASSICAL SPORONTOCIDAL DRUGS: PYRIMETHAMINE, PROGUANIL ACTIVE BUT LESS PRACTICAL: 8-AMINOQUINOLINES

Purine and pyrimidine precursors

$\left.\left.\underbrace{P A B \rightarrow \text { Folic }}_{A} \underbrace{\text { acid } \rightarrow \text { Folinic acid }}_{B} \rightarrow\right|_{C}\right|_{\text {Purines and pyrimidines }}$

after Rollo (102) 


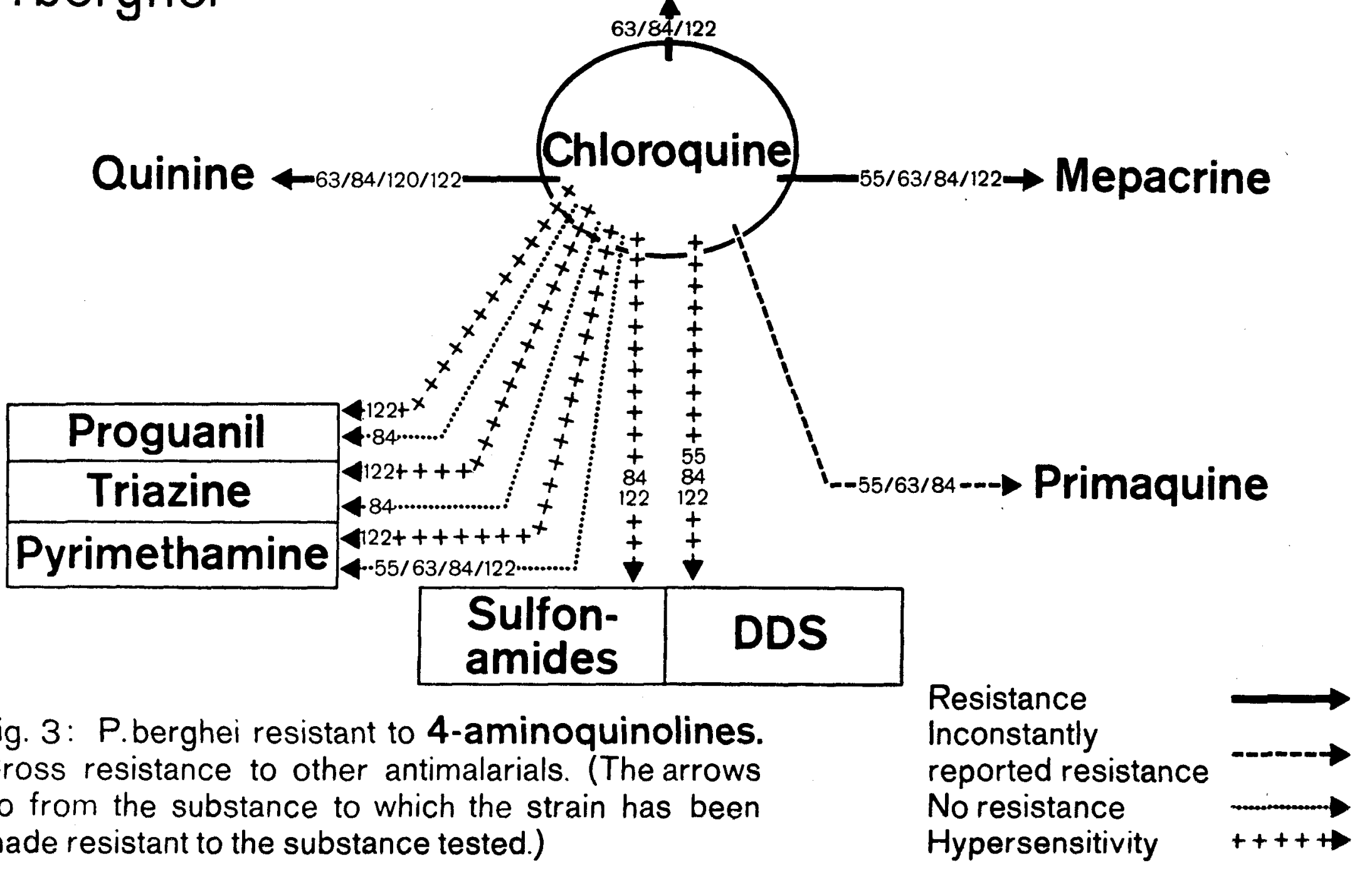




\section{Chloroquine}

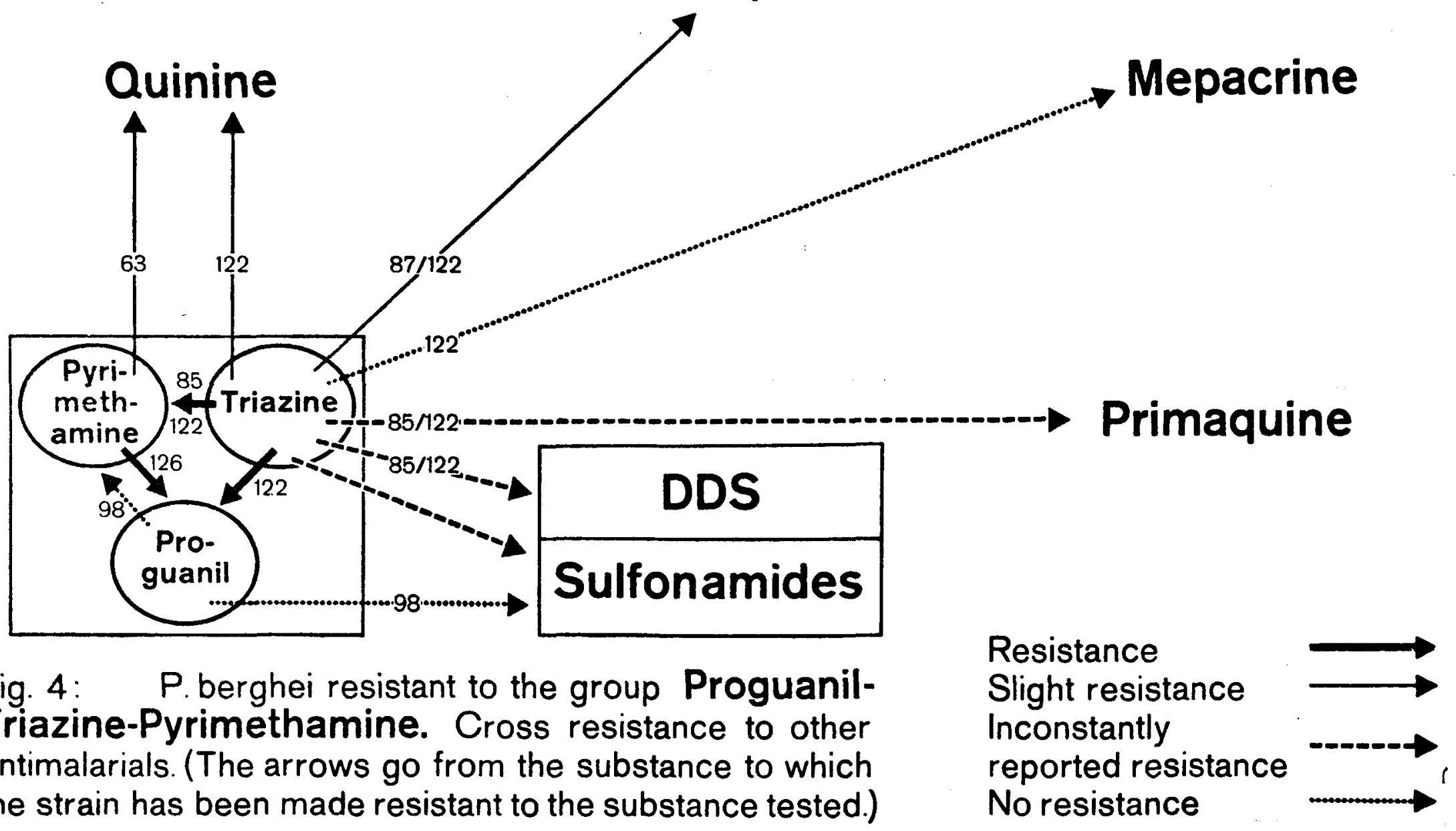




\section{P. berghei}

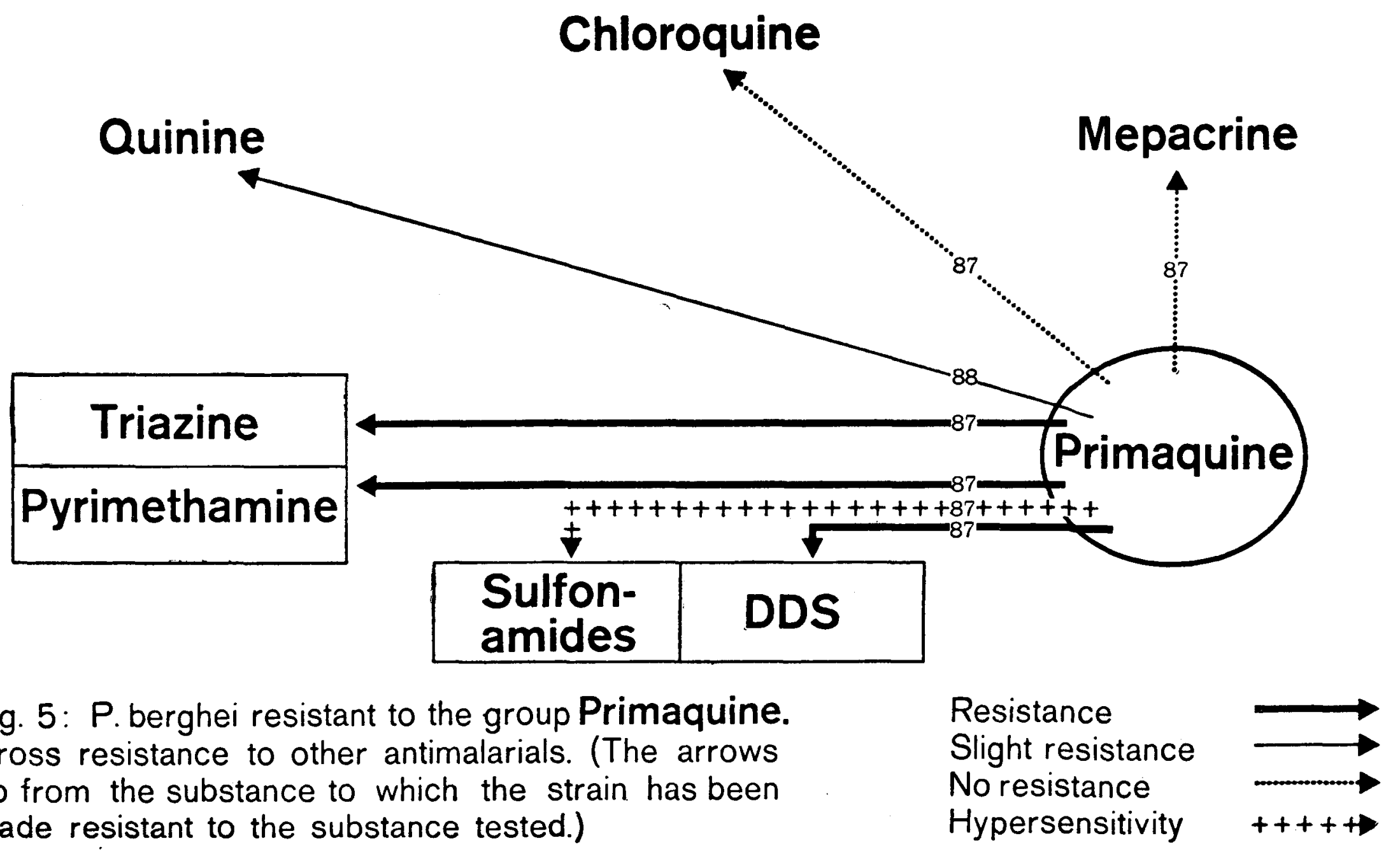




\section{P. berghei}

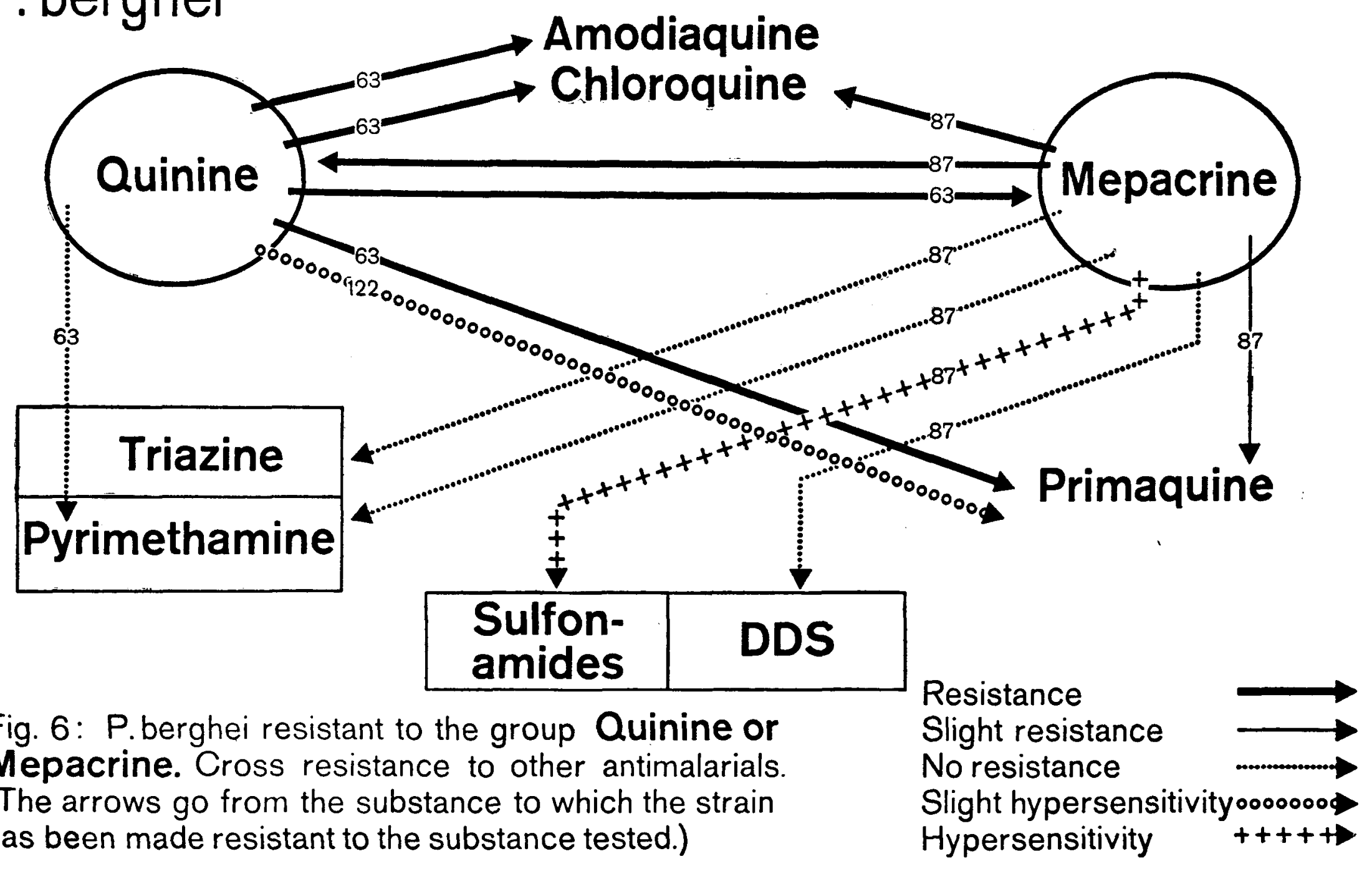




\section{P.gallinaceum}

\section{Chloroquine}

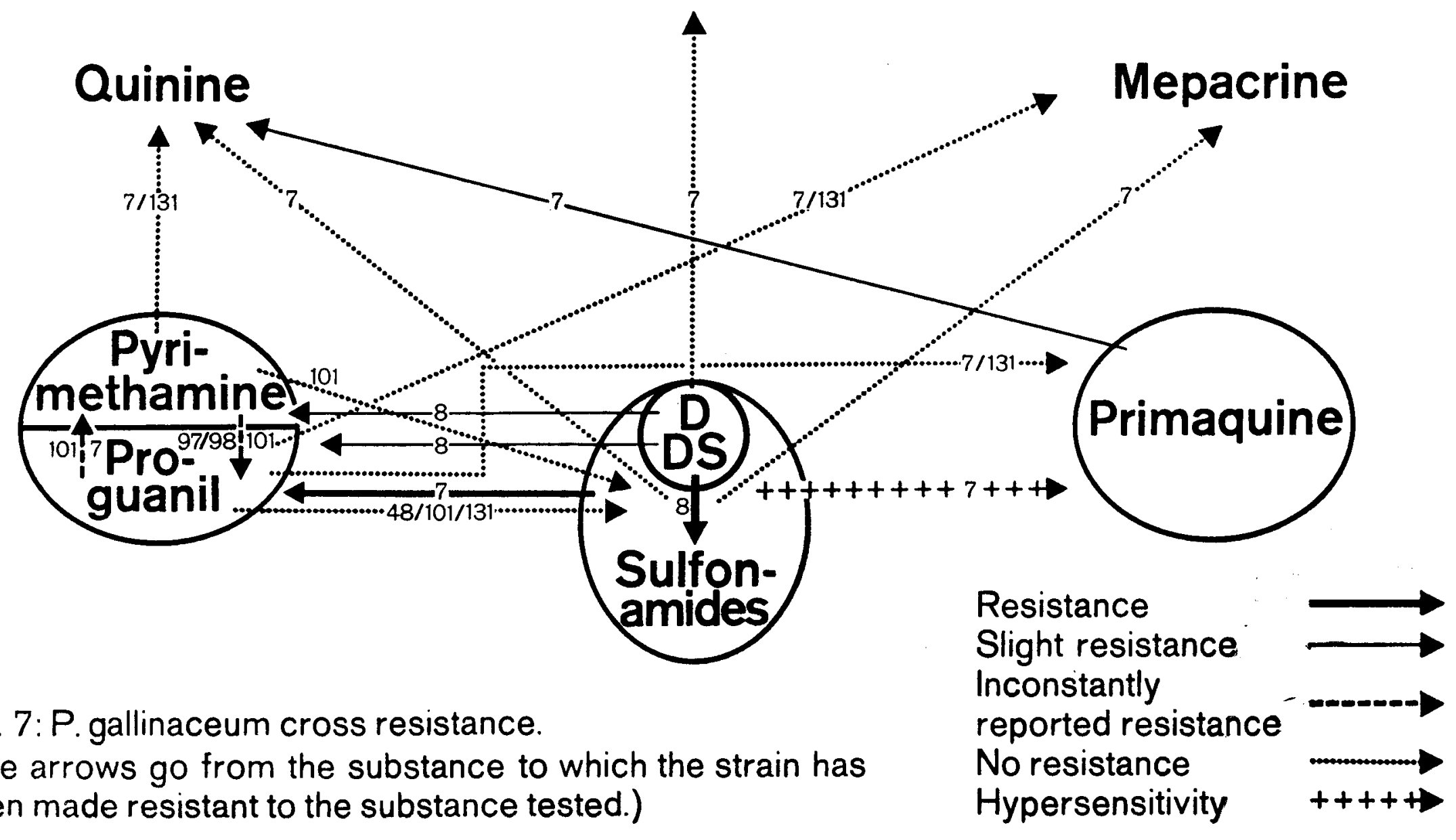

Fig. 7: P. gallinaceum cross resistance.

(The arrows go from the substance to which the strain has been made resistant to the substance tested.) 


\section{P. knowlesi}

\section{Chloroquine}

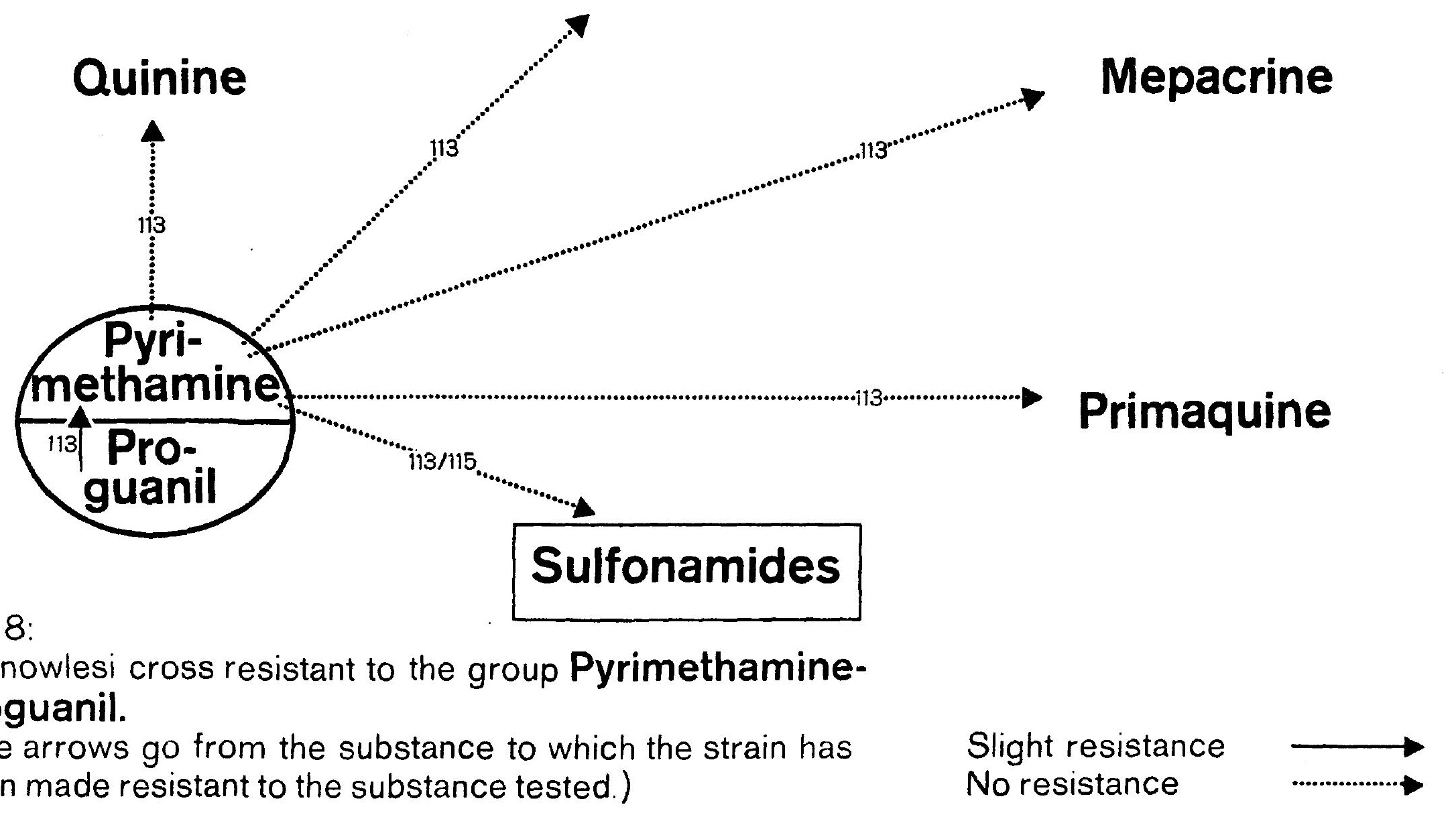

Fig. 8:

P. knowlesi cross resistant to the group PyrimethamineProguanil.

(The arrows go from the substance to which the strain has been made resistant to the substance tested.) 


\section{P. cynomolgi}

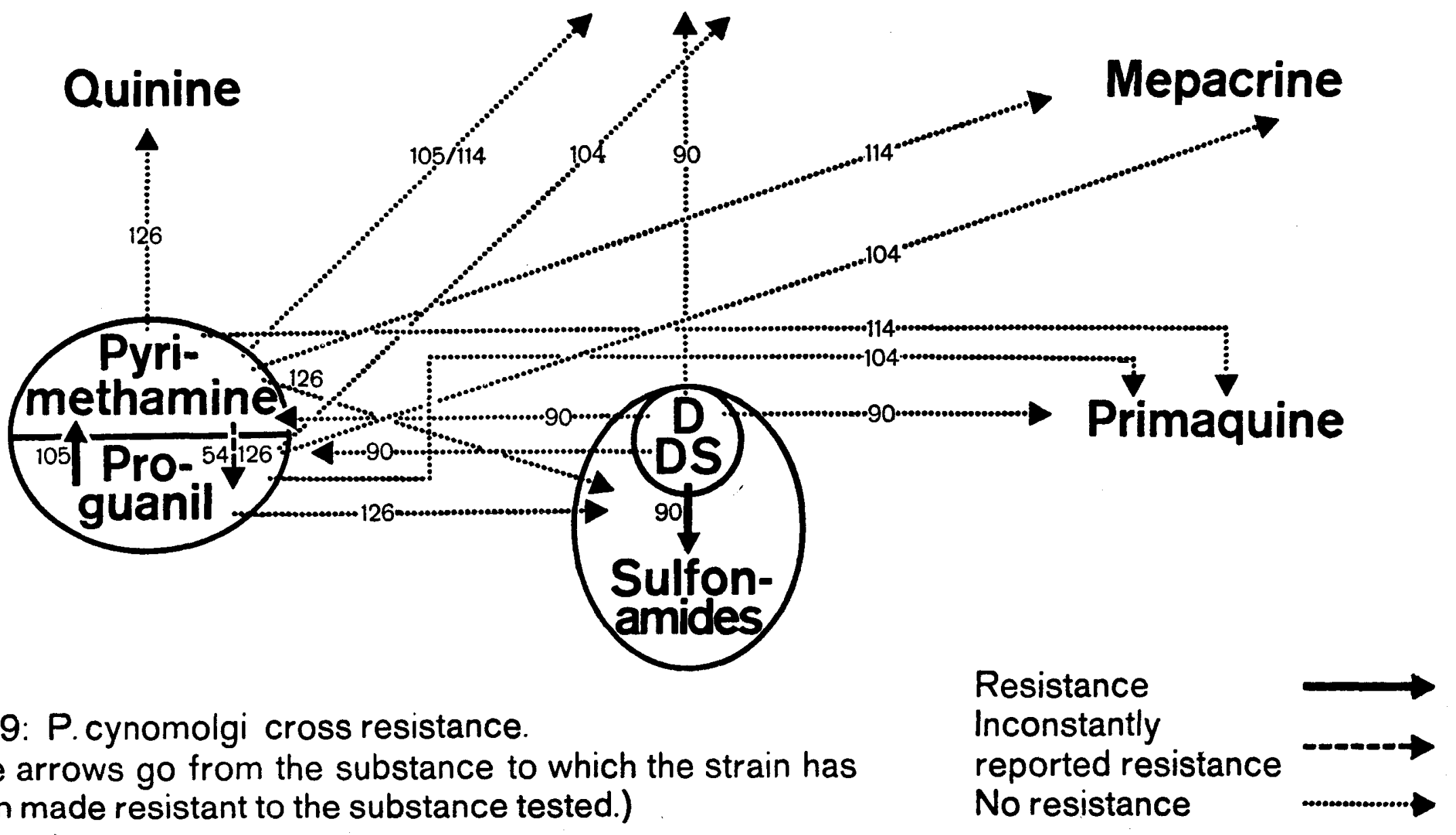

Fig. 9: P. cynomolgi cross resistance.

(The arrows go from the substance to which the strain has been made resistant to the substance tested.)

\section{Chloroquine}


Now to potentiation. The fact that sulfadiazine and other $\mathrm{p}$-aminobenzoic competitors with antimalarial activity are able to potentiate the action of proguanil against blood schizonts of $\boldsymbol{P}$. gallinaceum has been known since the work by Greenberg in 1949 (47, 49-50). Proguanil and pyrimethamine do not potentiate each other (101). Later on, it was proved that the same applies if the sulfonamide is replaced by a sulfone and/or if proguanil is replaced by pyrimethamine $(4-5,101)$. A similar potentiation has in the meantime also been confirmed in experimental and human toxoplasmosis $(34,44,59)$. In malaria, however, there had until 1963 been only a few tentative attempts to test the potentiating effect between sulfonamides and pyrimethamine in man (Hurly in 1959 (62); McGregor, Williams and Goodwin in 1963, (80).

In 1964, DeGowin and Powell (30) showed that $2,0 \mathrm{~g}$ sulfadiazine daily for 5 days given concurrently with 50 $\mathrm{mg}$ pyrimethamine daily for 3 days cured 5 out of 6 volunteers infected with the Malaya (Camp) strain of $P$. falciparum resistant to chloroquine, hydroxy-chloroquine, quinacrine, chlorguanide, and pyrimethamine. Previous trials with the same doses of sulfadiazine and pyrimethamine given separately had not been successful.

One month later, in December 1964, Laing (67) reported on the first results of his study of the antimalarial effect of Fanasil (Ro 4-4393). This sulfonamide shows the longest period of elimination ever described in man. It has a half-life of 100 to 200 hours. (Sulfadiazine: 17 hours). This permits therapeutically sufficient blood levels to be maintained by weekly administration of low doses, either orally or parenterally. The slow elimination is not due to any intentional conventional modification of the basic molecule (e. g. $\mathbf{N}_{1}$ - acetylation) or to the pharmaceutical presentation (e. g. repository injection or late release tablet), but to the intrinsic structure of the basic molecule itself. Oral absorption of Fanasil is as rapid as that of the usual sulfonamides. These two properties, rapid absorption and slow elimination, together with the good activity it has shown in the usual chemotherapeutic experimental tests $(96,128)$, have justified extensive clinical trials with the substance in the common indications of the sulfonamides $(1,25,64)$, with especial attention to those in which single-dose treatment (e.g. meningococcal meningitis in epidemic developing countries (39) and long-term treatments e.g. leprosy (3), trachoma (40), systemic mycoses (74) are most indicated.

On the basis of the experience gained during clinical trials in the treatment of about 15,000 cases (some 100 of them treated continuously for several years) it can be stated that the tolerance of Fanasil is at least as good as that of the most highly reputed sulfonamides. The possibility of oral weekly administration makes Fanasil quite suitable for combined treatment with pyrimethamine.

The activity of Fanasil in experimental malaria has been studied by Richards (94) (Table V). Fanasi] showed good antimalarial activity and a marked potentiation with pyrimethamine against sensitive strains as well as against strains of $P$. gallinaceum and $P$. berghei resistant to pyrimethamine, triazine or chloroquine. The pyrimethamine-resistant strain of $P$. gallinaceum was somewhat less sensitive to the potentiating mixture (pyrimethamine + Fanasil) than the normal strain. However, the resistance factor was only 2 to 5 , as compared with $>300$ for pyrimethamine alone.

These results have been confirmed in their main lines by Brener (9). The optimum potentiating ratio in these chemotherapeutic studies seems to be in the region of 10: 1 (Fanasil: pyrimethamine) but the range appears to be very broad. Prophylactic single-dose treatment showed that Fanasil has the most prolonged activity among other long-acting sulfonamides and DDS. 
Fanasil (20 $\mathrm{mg} / \mathrm{kg} \times \mathrm{7}$ ) and Fanasil pyrimethamine $(2.6 \mathrm{mg} \mathrm{kg}+$ $0.004 \mathrm{mg} / \mathrm{kg} \times \mathrm{7}$ ) were also effective against infection produced by $P$. gallinaceum sporozoites. Treated chicks remained free from parasites for the duration of the experiment (35 days of observation), whereas the controls died within 17 days (94). It seems therefore that there may also be a potentiation of the causal prophylactic effect.

Treatment of acute malaria with Fanasil alone or combined with pyrimethamine:

a) P. falciparum: Laing (68, 71, $72)$, working in Amani, Tanzania, i.e. in an area where pyrimethamine resistance is known to occur, has reported the following results:

A total of 105 "semi-immune" Bantu Africans seeking treatment for fever were treated with one dose of Fanasil ( $1 \mathrm{~g}$ ) alone (45 cases) or with one dose of $500 \mathrm{mg}$ Fanasil in combination with $12.5 \mathrm{mg}$ pyrimethamine (45 cases) or with one dose of chloroquine $(200 \mathrm{mg}$ i. $\mathrm{m}$. or $600 \mathrm{mg}$ orally) (15 cases) and thereafter a diagnosis of acute falciparum malaria was made by means of parasite counts from thick bloōd films. The results are shown in Table VI. In the group receiving Fanasil + pyrimethamine, asexual parasitemia was cleared in $88 \%$ of the patients within 48 hours compared to only $30 \%$ in the group receiving Fanasil alone. In another experience, two small children who had not responded to $50 \mathrm{mg}$ DDS did respond to $250 \mathrm{mg}$ Fanasil alone (69) .

In an unpublished study carried out recently in Malaya. Laing (72) tried Fanasil alone or with pyrimethamine in 62 "semi-immune" patients suffering from acute malaria due to
$P$. falciparum. The results are shown in Table VII. The treatment was considered to be a failure in those cases where asexual parasitemia was present on the seventh day of observation or where therapeutic intervention with another antimalarial drug was necessary in the interest of the patient. After a single dose of $1 \mathrm{~g}$ Fanasil given to 9 individuals there was one failure. Clearance of asexual parasitemia was somewhat slower than in African patients (average 3.1 days compared with 2.3 days). Various combinations of Fanasil (200 mg to $1 \mathrm{~g})$ with pyrimethamine (25 to $50 \mathrm{mg}$ ) gave similar results in 53 patients (6 failures) with an average duration of parasitemia of 2.2 days. Among the few patients receiving the highest dose of $1 \mathrm{~g}$ Fanasil $+50 \mathrm{mg}$ pyrimethamine there were no failures. 4 patients who had early recrudescences of parasitemia and febrile symptoms after treatment with chloroquine (1.5 $2.0 \mathrm{~g}$ orally over 3 to 4 days in 3 adults and $0.280 \mathrm{~g}$ parenterally in a two year old girl) were also treated with a single dose of Fanasil + pyrimethamine (1 $\mathrm{g}$ Fanasil $+25 \mathrm{mg}$ pyrimethamine for the adults and $250 \mathrm{mg}$ Fanasil $+6,25 \mathrm{mg}$ pyrimethamine for the child); three of the patients were "apparently cured" and one (an adult) to whom pyrimethamine was given 3 days prior to Fanasil showed no response to the dose of pyrimethamine, whereas after Fanasil scanty asexual parasitemia persisted for 7 days. Among 36 patients treated with 600 to 2,500 $\mathrm{mg}$ chloroquine there were 11 failures

In Bangkok, Harinasuta (52) gave Fanasil alone or in combination with pyrimethamine or chloroquine to 66 patients (adults) with recrudescences after chloroquine-resistant acute $P$. falciparum malaria. The preli- 
The antimalarial activity against drug sensitive and drug resistant strains of P. gallinaceum and P. berghei.

Results expressed as the level of drug which reduces the parasitemia to $50 \%$ of the untreated controls $\left(\mathrm{ED}_{50}\right)$ (Richards ${ }^{94}$ )

\begin{tabular}{|c|c|c|c|c|c|}
\hline \multirow{3}{*}{ Drug } & \multicolumn{5}{|c|}{$\mathrm{ED}_{50}(\mathrm{mg} / \mathrm{kg} \times 7$ orally $)$} \\
\hline & \multicolumn{3}{|c|}{ P. gallinaceum } & \multicolumn{2}{|c|}{ P. berghe1 } \\
\hline & $\begin{array}{l}\text { Pyrime thamine } \\
\text { sensitive } \\
\text { strain }\end{array}$ & $\begin{array}{l}\text { Pyrimethamine } \\
\text { resistant } \\
>300 x\end{array}$ & $\begin{array}{l}\text { Triazine } \\
\text { resistant } \\
>25 x\end{array}$ & $\begin{array}{l}\text { Chloroquine } \\
\text { sensitive } \\
\text { strain }\end{array}$ & $\begin{array}{l}\text { Chloroquine } \\
\text { resistant } \\
>12 \times\end{array}$ \\
\hline Pyrime thamine & 0.03 & $>10$ & - & 0.15 & 0.15 \\
\hline Sulphorthomidine & 20.0 & 25 & 25 & 1.0 & 1.0 \\
\hline $\begin{array}{l}\text { Sulphor thomldine } \\
+ \text { pyrimethamine }\end{array}$ & $\begin{array}{l}2.6+ \\
0.004\end{array}$ & $\begin{array}{l}5+ \\
0.02\end{array}$ & - & $\begin{array}{l}0.1+ \\
0.0125\end{array}$ & $\begin{array}{l}0.1+ \\
0.0125\end{array}$ \\
\hline Chloroquine & - & - & - & 8.0 & $>100.0$, toxic \\
\hline
\end{tabular}


Average duration of asexual parasitaemia of $P$. falciparum and fever after treatment with Fanasil alone and in combination with pyrimethamine (Laing, Tanzania ${ }^{71,72}$ )

\begin{tabular}{|l|c|c|c|c|}
\hline Drug & No. of Pats. & Fallures* & \multicolumn{2}{|c|}{ Mean duration in days } \\
\hline Fanas1l** $1 \mathrm{~g}$ & 45 & 7 & 2.3 & Parasitaemia \\
(19 cases) \\
\hline $\begin{array}{l}\text { Fanasil } 500 \mathrm{mg} * * * \\
\text { Pyrimethamine 12.5 mg }\end{array}$ & 45 & 0 & 1.8 & $\begin{array}{l}1.5 \\
\text { cases) }\end{array}$ \\
\hline $\begin{array}{l}\text { Chloroquine } \\
200 \mathrm{mg} \text { 1.m. or } \\
600 \mathrm{mg} \text { oraily }\end{array}$ & 15 & 0 & 1.7 & - \\
\hline
\end{tabular}

* Parasites still present in blood films on the 7 th day or other drug required before the 7 th day.

* Children up to 11 years received 250 to $750 \mathrm{mg}$

*** Children up to 11 years received 125 to $375 \mathrm{mg}$ 
Effect of Fanasil given alone or in combination with Daraprim or chloroquine to adult patients with chloroquine-resistant falciparum malaria (Harinasuta, Thailand 52 )

\begin{tabular}{|c|c|c|c|c|c|c|c|}
\hline \multirow[t]{2}{*}{$\begin{array}{l}\text { Drug regimen } \\
\text { (single dose)* }\end{array}$} & \multirow{2}{*}{$\begin{array}{l}\text { No. of } \\
\text { patients } \\
\text { treated }\end{array}$} & \multicolumn{2}{|c|}{ Successes } & \multicolumn{2}{|c|}{ Failures } & \multicolumn{2}{|c|}{$\begin{array}{l}\text { Average duration of parasitemia } \\
+ \text { fever in days (excl. failures) }\end{array}$} \\
\hline & & cured & cleared ** & C.T.E. & P.T.E. & Parasitemia & Fever \\
\hline Fanasil $1 \mathrm{~g}$ & 16 & 9 & 2 & - & 5 & 5 & 2.1 \\
\hline Fanasil $1.5 \mathrm{~g}$ & 7 & 2 & 2 & 2 & 1 & 4.6 & 2.3 \\
\hline $\begin{array}{c}\text { Fanasil } 250 \mathrm{mg} \\
+ \\
\text { Daraprim } 12.5 \mathrm{mg}\end{array}$ & 6 & 4 & 1 & 1 & - & 4 & 2 \\
\hline $\begin{array}{c}\text { Fanasil } 250 \mathrm{mg} \\
+ \\
\text { Daraprim } 25 \mathrm{mg}\end{array}$ & 15 & 10 & - & 2 & 3 & 3.6 & 2.7 \\
\hline $\begin{array}{c}\text { Fanasil } 0.5 \mathrm{~g} \\
+ \\
\text { Daraprim } 25 \mathrm{mg}\end{array}$ & 5 & 1 & 2 & 2 & - & 4.1 & 0.6 \\
\hline $\begin{array}{l}\text { Panasil } 1 \mathrm{~g} \\
+ \\
\text { Chloroquine } 1.5 \mathrm{~g} \\
\text { (in } 3 \text { days) }\end{array}$ & 17 & 13 & - & 2 & 2 & 4 & 1.5 \\
\hline
\end{tabular}

* except for chloroquine

* with a follow-up of less than 28 days

C.T.E. = complete temporary effect (clearance of asexual parasitemia with subsequent relapse)

P.T.B. = partial temporary effect (reduction not abolition of asexual parasitemia) 
minary results are shown in Table VIII. On the basis of clinical response and duration of parasitemia, the best results were obtained with the following combinations: A) $1 \mathrm{~g}$ Fanasil (single dose) $+1.5 \mathrm{~g}$ chloroquine in three days); B) $0.5 \mathrm{~g}$ Fanasil $+25 \mathrm{mg}$ pyrimethamine in a single dose. The latter has the practical advantage of being a one-dose therapy. Since duration of parasitemia is longer than that seen after chloroquine in chloroquine-sensitive cases, further trials are being carried out with higher doses of the combination Fanasil + pyrimethamine.

Sensitivity to chemotherapy of seven strains of $P$. falciparum found in four Brazilian regions, in patients who did not respond satisfactorily to chloroquine, was studied by Lopes and Rodrigues da Silva (75) in 25 neurosyphilitic patient with blood-induced malaria. All seven strains show ed resistance to the standard "field--test" dose (10 $\mathrm{mg} / \mathrm{kg}$ of chloroquine recomended by WHO for preliminary selection of suspected chloroquine-resistant strains). Three of the seven strains turned out to be only partially chloroquine - resistant, s in ce parasitemia disappeared after a higher dose of chloroquine ( $3 \mathrm{~g}$ in 3 days). The other four strains were considered as fully resistant to chloroquine; two of them were also resistant to pyrimethamine, and at least partially, to quinine. These two last strains ( $\mathrm{Po}_{2 .}$ and $\mathrm{Po}_{3}$ ), i. e., those fully or partially resistant to the three above mentioned major antimalarials, were sensitive to Fanasil combined with pyrimethamine. As shown in Table IX, the therapeutic response (8 cases), however, took place rather slowly. Clinical response was achieved in 4 to 8 days, the trophozoi- tes disappeared from the blood in 4 to 6 days and the gametocytes in about a month.

Almeida, Brazil, (2) has reported on the preliminary results of an extensive study being carried out in cases of spontaneous malaria. The patients are followed up for 6 days after receiving one of the $t h \mathrm{ree}$ following treatments: Group A) $10 \mathrm{mg} / \mathrm{kg}$ chloroquine, 5 days later 10 $\mathrm{mg} / \mathrm{kg}$ chloroquine and $5 \mathrm{mg}$, $\mathrm{kg}$ chloroquine on each of the 2 following days (total dose 30 $\mathrm{mg} / \mathrm{kg}$ in 8 days). Group B) 40 $\mathrm{mg} / \mathrm{kg}$ chloroquine in 4 days. Group C) $1 \mathrm{~g}$ Fanasil and $50 \mathrm{mg}$ pyrimethamine on the first day and $0,5 \mathrm{~g}$ Fanasil on the following day. According to the preliminary results (197 courses of treatment in 178 patients followed), some cases of the groups $A$ and $B$ have shown recrudescences during the follow-up period. In the group $C$ (14 cases already observed over 60 days) 4 cases became negative during the first day of treatment and the other 10 cases during the second one. All of them remained negative over the followup period.

Peringle and Lane (89), Tanzania, have reported on the results obtained with $250 \mathrm{mg}$ Fanasil in 9 schoolchildren who developed one or two clinical fits of falciparum malaria three to six months after the injection of the repository antimalarials cycloguanil pamoate, or DADDS, or both (Table $\mathrm{X}$ ). BV the fourth day after the dose of Fanasil trophozoites had disappeared from the blood in all cases.

b) $P$. vivax. Confirming the results obtained by previous workers with older sulfonamides, Laing in Malaya also found $P$. vivax to be less sensitive to Fanasil than $P$. falciparum (Table VII) (72). Out of 13 patients with acute vivax malaria treated with $1 \mathrm{~g}$. 
Table IX

Therapeutic response to the association

Ro 4-4393 + Pyrimethamine

(Lopes and da Silva, Brazil ${ }^{75}$ )

\begin{tabular}{|c|c|c|c|c|}
\hline \multirow{2}{*}{$\begin{array}{l}\text { No. of } \\
\text { patient }\end{array}$} & \multirow{2}{*}{$\begin{array}{l}\text { Ro } 4-4393 / 2 \\
\text { + pyrimethamine }\end{array}$} & \multirow{2}{*}{$\begin{array}{l}\text { Clinical } \\
\text { response }\end{array}$} & \multicolumn{2}{|c|}{ Parasitemia } \\
\hline & & & Pet & $\mathrm{PIB}_{8}$ \\
\hline 18 & $\int_{5}^{500 \mathrm{mg}}+50 \mathrm{mg}$ & $5 d$ & $5 d$ & $30 d$ \\
\hline 13 & Idem & $5 d$ & $4 d$ & $30 d$ \\
\hline 21 & Idem & $6 \mathrm{~d}$ & $5 d$ & $28 d$ \\
\hline 8 & $18+50 \mathrm{mg}$ & $5 \mathrm{~d}$ & $4 d$ & $11 \mathrm{~d}^{*}$ \\
\hline 25 & Idem & $8 d$ & $5 d$ & $24 d *$ \\
\hline 26 & Idem & $4 d$ & $4 d$ & $8 d *$ \\
\hline 27 & Idem & $5 d$ & $5 d$ & $7 d *$ \\
\hline 19 & Idem & $5 d$ & $6 d$ & $17 d^{*}$ \\
\hline
\end{tabular}

* under observation

$$
\begin{aligned}
\text { PIt } & =\text { trophozoltes (P. falciparum) } \\
\text { PIg } & =\text { gametocytes (P. Ialciparum) } \\
\text { d } & =\text { days }
\end{aligned}
$$


Results obtained with a single dose of $250 \mathrm{mg}$ Fanasil in 7 patients having developed clinical falciparum malaria 3 to 6 months after the injection of a repository antimalarial (cycloguanyl pamoate, diacetyldiaminodiphenylsulfone or both)

(Pringle and Lane, Tanzania ${ }^{89}$ )

\begin{tabular}{|c|c|c|c|c|c|c|c|c|c|}
\hline \multirow{2}{*}{$\begin{array}{l}\text { Subject } \\
\text { code } \\
\text { number: }\end{array}$} & \multirow[t]{2}{*}{$\begin{array}{l}\text { Age in } \\
\text { years }\end{array}$} & \multirow[t]{2}{*}{$\begin{array}{c}\text { Repository } \\
\text { drug }\end{array}$} & \multirow{2}{*}{$\begin{array}{l}\text { Dose of } \\
\text { rep.drug } \\
\text { in } \mathrm{mg} / \mathrm{kg} \text {. }\end{array}$} & \multirow{2}{*}{$\begin{array}{l}\text { Interval after } \\
\text { injection of } \\
\text { rep. drug: }\end{array}$} & \multicolumn{5}{|c|}{$\begin{aligned} \text { Trophozoite counts per cu. mm. on } \\
\text { post-treatment days }\end{aligned}$} \\
\hline & & & & & Pre-treatment: & Day 1 & Day 2 & Day 3 & Day 4 \\
\hline $\mathrm{BB} / 10$ & 12 & $\mathrm{Cl}-501$ & 10.8 & $D+85$ & 7.440 & Neg. & Neg. & Neg. & Neg. \\
\hline$A B / 4$ & 9 & $"$ & 12.4 & $D+137$ & 17.200 & 65 & Neg. & Neg. & Neg. \\
\hline$A B / 21$ & 10 & $"$ & 11.8 & $D+179$ & 80.360 & 32 & 112 & 48 & Neg. \\
\hline $\mathrm{AY} / 27$ & 8 & $C 1-556$ & 8.4 & $D+148$ & 8.400 & 14.520 & Neg. & Neg. & Neg. \\
\hline$"$ & $"$ & $"$ & $"$ & $D+199$ & 2.380 & 3360 & Neg. & Neg. & Neg. \\
\hline $\mathrm{AY} / 17$ & 8 & $"$ & 7.0 & $D+200$ & 44.560 & 4800 & 2.500 & 3.240 & Neg. \\
\hline $\mathrm{AG} / 5$ & 9 & $C 1-564$ & 24.3 & $D+140$ & 8.800 & 820 & Neg. & Neg. & Neg. \\
\hline$"$ & $"$ & $"$ & $"$ & $D+196$ & 21.600 & 1640 & Neg. & Neg. & Neg. \\
\hline$A G / 26$ & 8 & $"$ & 13.2 & $D+172$ & 27.500 & 600 & Neg. & Neg. & Neg. \\
\hline
\end{tabular}


Fanasil, 5 were failures. Out of 14 treated with Fanasil + pyrimethamine 2 were failures. However, on the average the parasitemia disappeared as quickly as in falciparum cases that responded. Higher doses should be tried in view of the fact that another investigator in Indonesia has obtained preliminary results in $P$. vivax which are at least as good as those he obtained in $P$. falciparum (61).

c) $P$. malariae and $P$. ovale. The scanty material available on these two species seems to indicate that they respond worse to Fanasil than $P$. falciparum, but that the association Fanasil + pyrimethamine is active.

Suppressive treatment with Fanasil alone and combined with pyrimethamine.

a) $P$. falciparum. The effect of single and weekly administration of Fanasil, pyrimethamine, and their combination on parasitemia due to $P$. falciparum in schoolchildren was extensively studied by Laing in Tanzania $(66,72)$. The results are summarized in Table XI. It seems that in schoolchildren doses as low as $125 \mathrm{mg}$ Fanasil weekly we re capable of suppressing asymptomatic asexual parasitemia in the great majority but not in all cases. No failures were seen when this dose (or even less) was combined with 6.25 or $12.5 \mathrm{mg}$ pyrimethamine. Pyrimethamine alone was not effective since $38 \%$ and $18 \%$ of the children still had asexual parasitemia 7 days after one dose of 25 and $75 \mathrm{mg}$ respectively. Even after 4 to 6 weekly doses of $25 \mathrm{mg}$ pyrimethamine, $27 \%$ of the children were stili positive.

In the same holoendemic area in Northeastern Tanzania, Prin- gle and Lane (89) had the opportunity of testing the suppressive effect of Fanasil and Dapsone on break-through parasitemias among children previously injected with one of the above mentioned repository antimalarial agents. These substances had been administered during a drug trial conducted 5 months previously. As shown in Table XII a single dose of $100 \mathrm{mg}$ Fanasil was first given to patients of the biguanide and sulfone groups. Out of 34 trophozoite carriers, only two had scanty parasitemia one week later, whereas 13 were again positive after one month. At that time the patients of these two groups received one $100 \mathrm{mg}$ dose of Dapsone which failed to suppress parasitemia in 2 cases. Two and a half months later, the three groups (biguanide, sulfone and combined) were given either $100 \mathrm{mg}$ Fanasil (68 patients) or $100 \mathrm{mg}$ Dapsone (54 patients). Fifty days later the same patients received 50 mg Fanasil or Dapsone. From the overall results it appears that Fanasil was the more effective drug in suppressing such break-through parasitemias.

Shute and Dowling (110) compared the suppressive action of Fanasil and chloroquine on parasitemia in schoolchildren living in the Western region of $\mathrm{Ni}$ geria where malaria is holoendemic. As shown in Table XIII, the children of each of three large schools received one of the following drug regimens: Fanasil $500 \mathrm{mg}$ once a week for 4 weeks, Fanasil $500 \mathrm{mg}$ as a single dose, or chloroquine $300 \mathrm{mg}$ as a single dose. No treatment was given in two smaller schools where the children were considered as controls. Blood surveys (thick blood films) were carried out before the beginning of the trials and at weekly intervals for 4 weeks thereafter. 
Effect of Fanasil and pyrimethamine given alone or in combination against pyrimethamine-resistant Plasmodium falciparum in semiimmune schoolchildren with a pre-treatment parasite incidence of over $25 \%$ (Laing, Ianzania 66,72 )

No. of children

examined
Dosage

Fanasil alone

176

140

37

36

35

33
$500 \mathrm{mg} /$ week for 4-6 weeks $250 \mathrm{mg} /$ week for 8 weeks

$125 \mathrm{mg} \times 1$

$100 \mathrm{mg} \times 1$

$75 \mathrm{mg} x 1$

$50 \mathrm{mg} \times 1$

$25 \mathrm{mg} \times 1$
No. of children with trophozoites

Fanasil (F) + pyrimethamine (P)

\begin{tabular}{|c|c|c|}
\hline 178 & $\begin{array}{l}\text { F } 500 \mathrm{mg}+\mathrm{P} 25 \mathrm{mg} \text { once } \\
\text { weekly for } 4-6 \text { weeks }\end{array}$ & 0 \\
\hline 159 & $\begin{array}{l}\mathrm{F} 250 \mathrm{mg}+\mathrm{P} 12.5 \mathrm{mg} / \text { week } \\
\text { for } 8 \text { weeks }\end{array}$ & $\begin{array}{l}0 \text { (after } 2 \text { doses) } \\
1 \text { (after } 4 \text { doses) } \\
0 \text { (after } 6 \text { \& } 8 \text { d.) }\end{array}$ \\
\hline 125 & $\mathrm{~F} 125 \mathrm{mg}+\mathrm{P} 12.5 \mathrm{mg} \times 1$ & 0 \\
\hline 54 & $\mathrm{~F} 100 \mathrm{mg}+\mathrm{P} 12.5 \mathrm{mg} \times \mathrm{I}$ & 0 \\
\hline 83 & $F \quad 75 \mathrm{mg}+P 12.5 \mathrm{mg} \times 1$ & 0 \\
\hline 39 & $\mathrm{~F} \quad 50 \mathrm{mg}+\mathrm{P} 12.5 \mathrm{mg} \times \mathrm{I}$ & 2 \\
\hline 37 & F $25 \mathrm{mg}+\mathrm{P} 12.5 \mathrm{mg} \times \mathrm{I}$ & 4 \\
\hline 39 & $\mathrm{~F} 125 \mathrm{mg}+\mathrm{P} 6.25 \mathrm{mg} \times \mathrm{I}$ & 0 \\
\hline 29 & $\mathrm{~F} 100 \mathrm{mg}+\mathrm{P} 6.25 \mathrm{mg} \times \mathrm{I}$ & 0 \\
\hline 33 & F $75 \mathrm{mg}+P 6.25 \mathrm{mg} \times I$ & 1 \\
\hline \multicolumn{3}{|c|}{ Pyrimethamine alone } \\
\hline 133 & $12.5 \mathrm{mg}$ for 8 weeks & $\begin{array}{l}17 \text { (after } 2 \text { doses) } \\
19 \text { (after } 4 \text { doses) } \\
17 \text { (after } 6 \text { doses) } \\
16 \text { (after } 8 \text { doses) }\end{array}$ \\
\hline 122 & $75 \mathrm{mg} \times 1$ & $22 \quad(18 \%)$ \\
\hline 123 & $25 \mathrm{mg} \times 1$ & $47(38 \%)$ \\
\hline 684 & $25 \mathrm{mg} /$ week for 4-6 weeks & $184(27 \%)$ \\
\hline Untreat & & \\
\hline 67 & & $48 \quad(71 \%)$ \\
\hline
\end{tabular}

Pyrimethamine alone

133

$12.5 \mathrm{mg}$ for 8 weeks

17 (after 2 doses)

1 (after 2 doses)

0 (after 4 doses)

2 (after 8 doses)

O (1 P. ovale)

4

1

2

3 
Response of asymptomat1c parasitemias occurring among children (previously injected with a repository antimalarial) to single doses of Panasil or Dapsone

(Pringle and Lane, Tanzania ${ }^{89}$ )

\begin{tabular}{|c|c|c|c|c|c|}
\hline \multirow{2}{*}{$\begin{array}{l}\text { Drug and } \\
\text { dose }\end{array}$} & \multirow{2}{*}{$\begin{array}{l}\text { Type of re- } \\
\text { pository drug }\end{array}$} & \multirow{2}{*}{$\begin{array}{l}\text { Days since } \\
\text { injection }\end{array}$} & \multirow{2}{*}{$\begin{array}{l}\text { No. of } \\
\text { patients }\end{array}$} & \multicolumn{2}{|c|}{$\begin{array}{l}\text { Patients with trophozoltes of P. falciparum } \\
\text { before and after the "super-treatment" }\end{array}$} \\
\hline & & & & Before treatment & One week later \\
\hline $\begin{array}{l}\text { Panas } 11 \\
100 \mathrm{mg}\end{array}$ & $\begin{array}{l}\text { Blguanido } \\
\text { Sulfone }\end{array}$ & 250 & $\begin{array}{l}57 \\
53\end{array}$ & $\begin{array}{l}26 \\
18\end{array}$ & $\begin{array}{l}1 * \\
1 *\end{array}$ \\
\hline $\begin{array}{l}\text { Dapsone } \\
100 \text { ing }\end{array}$ & $\begin{array}{l}\text { Biguanide } \\
\text { Sulfone }\end{array}$ & 182 & $\begin{array}{l}59 \\
59\end{array}$ & $\begin{array}{l}6 \\
7\end{array}$ & $\begin{array}{l}0 \\
2\end{array}$ \\
\hline $\begin{array}{l}\text { Panas 11 } \\
100 \mathrm{mg}\end{array}$ & $\begin{array}{l}\text { B1guanide } \\
\text { Sulfone } \\
\text { Combined }\end{array}$ & 254 & $\begin{array}{l}28 \\
22 \\
18 \\
\end{array}$ & $\begin{array}{l}13 \\
10 \\
11 \\
\end{array}$ & $\begin{array}{l}0 \\
0 \\
0\end{array}$ \\
\hline $\begin{array}{l}\text { Dapsone } \\
100 \mathrm{mg}\end{array}$ & $\begin{array}{l}\text { B1guanide } \\
\text { Sulfone } \\
\text { Combined }\end{array}$ & 254 & $\begin{array}{l}13 \\
21 \\
20\end{array}$ & $\begin{array}{l}6 \\
8 \\
6\end{array}$ & $\begin{array}{l}1 \\
3 \\
0\end{array}$ \\
\hline $\begin{array}{l}\text { Panas 11 } \\
50 \mathrm{mg}\end{array}$ & $\begin{array}{l}\text { Blguanide } \\
\text { Sulfone } \\
\text { Combined }\end{array}$ & 305 & $\begin{array}{l}29 \\
22 \\
18\end{array}$ & $\begin{array}{l}13 \\
10 \\
11\end{array}$ & $\begin{array}{l}0 \\
0 \\
0\end{array}$ \\
\hline $\begin{array}{l}\text { Depsone } \\
50 \mathrm{mg}\end{array}$ & $\begin{array}{l}\text { Biguanide } \\
\text { Sulfone } \\
\text { Comblned }\end{array}$ & 305 & $\begin{array}{l}13 \\
24 \\
19\end{array}$ & $\begin{array}{l}6 \\
10 \\
10\end{array}$ & $\begin{array}{l}0 \\
1 \\
0\end{array}$ \\
\hline
\end{tabular}

- In both of these cases the parasite density was extremely low 
The untreated controls showed continuing falciparum parasitemia irs 69 to $81 \%$ of the cases throughout the trial. Both regimens of Fanasil were found to be highly effective against asexual $P$. falciparum parasitemia as from the first week when all cases were negative. In the Fanasil groups, the highest incidence of children with trophozoites was $2 \%$ after 4 weeks (in the single dose group), whereas in the chloroquine group the incidence of positive cases was $5 \%$ after one week and progressively increasing to $16 \%$ after 4 weeks.

b) $P$. malariae. Shute and Dowling (110) also registered quite a high pre-treatment incidence of asexual parasitemia due to $P$. malariae during the surveys in the above mentioned Nigerian schools. The rates of positive cases before and after treatment are given on the extreme right of Table XIII which shows a rate of 10 to $15 \%$ prior to treatment, increasing to $19 \%$ after 4 weeks in the control group. This table also shows that the effect of chloroquine on $P$. malariae was entirely satisfactory and that both regimens of Fanasil were almost as effective as chloroquine

Recent (unpublished) work carried out in Indonesia (61) indicates that Fanasil given alone or together with pyrimethamine is capable of completely suppressing $P$. malariae parasitemia by the second week after the first dose. Confirmatory trials are being undertaken.

c) P. vivax and $P$. ovale. The number of cases treated with Fanasil is too small to permit evaluation of the results. In Africa, Laing (72) observed the emergence of $\mathrm{P}$. ovale in 2 patients having received weekly doses of $250 \mathrm{mg}$ Fanasil. In another case trophozoites persisted after one dose of $1 \mathrm{~g}$ Fanasil. Shute and Dowling (110) observed per- sistence of $P$. ovale in 6 schoolchildren treated with Fanasil. In 3 further cases the trophozoites apparently emerged during suppressive treatment with Fanasil. In Indonesia, clearance of $P$. vivax parasitemia seems to have been rather slow, complete clearance having been achieved 3 weeks after the beginning of treatment with Fanasil, with or without pyrimethamine, given as a single dose or once weekly.

Gametocytocidal effect: According to the findings reported by Shute and Dowling (110) and by Laing $(66,72)$, Fanasil has actually no gametocytocidal effects, the slow disapearance of sexual forms of $P$. falciparum being the result of the schizonticidal action of the drug?

Effect on sporogony: Investigations were carried out by Laing $(70,72)$ to determine the effect of Fanasil alone and combined with pyrimethamine on falciparum sporogony. Batches of laboratory-bred Anopheles gambiae were fed on patients with sexual parasitemia after treament. All surviving mosquitoes were negative after having fed on 2 patients previously treated with $500 \mathrm{mg}$ Fanasil +12.5 mg pyrimethamine. The same result was obtained in a further 2 patients after the combination of $500 \mathrm{mg} \mathrm{Fa}$ nasil and $6.25 \mathrm{mg}$ pyrimethamine. However, when a $1 \mathrm{~g}$ dose of Fanasil alone was given to a patient on two occasions, a significant number of mosquitoes were found to be positive after each dose. Consequently Fanasil alone does not seem to affect normal falciparum sporogony in mosquitoes. When given together with a small dose of pyrimethamine, which may be insufficient in itself, there appears to be potentiation of the sporontocidal effect of the latter. In experimental malaria ( $P$. gallinaceum) such a potentiation has already been described by Ramakrishnan et al. (91) for DDS, although given by itself this substance did not show any sporontocidal effect. 
Bffect of Fanasil and chloroquine on asexual parasitemia in

African schoolchildren of 6 to 14 years (control group 6 to 11 years) (Shute and Dowling,Nigeria ${ }^{110}$ )

\begin{tabular}{|c|c|c|c|c|c|c|}
\hline \multirow{2}{*}{$\begin{array}{l}\text { Drug and dosage } \\
============-===\end{array}$} & \multirow{2}{*}{ 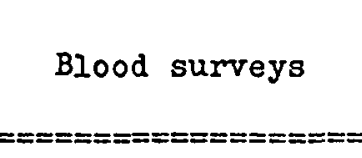 } & \multirow{2}{*}{$\begin{array}{l}\text { No. of } \\
\text { patients } \\
\text { examined } \\
=========\end{array}$} & \multicolumn{2}{|c|}{ P. falciparum } & \multicolumn{2}{|c|}{ P. malariae } \\
\hline & & & $\begin{array}{l}\text { Positive } \\
========\end{array}$ & Rate \% & $\begin{array}{l}\text { Positive } \\
:==== \pm====\end{array}$ & Rate $\%$ \\
\hline \multirow{5}{*}{$\begin{array}{l}\text { Fanasil } 500 \mathrm{mg} \\
\text { once a week for } \\
4 \text { weeks. }\end{array}$} & Before treatment & 209 & 161 & 77 & 21 & 10 \\
\hline & after: 1 week & 195 & 0 & - & 5 & 3 \\
\hline & 2 weeks & 194 & 0 & - & 0 & - \\
\hline & 3 weeks & 189 & 1 & 0.5 & 0 & - \\
\hline & 4 weeks & 185 & 1 & 0.5 & 0 & - \\
\hline \multirow{5}{*}{$\begin{array}{l}\text { Fanasil } 500 \mathrm{mg} \\
\text { single dose }\end{array}$} & Before treatment & 261 & 175 & 67 & 39 & 15 \\
\hline & after: 1 week & 240 & 0 & - & 2 & 2 \\
\hline & 2 weeks & 237 & 2 & 1 & 0 & - \\
\hline & 3 weeks & 238 & 1 & 0.5 & 1 & 0.5 \\
\hline & 4 weeks & 233 & 4 & 2 & 0 & - \\
\hline \multirow{5}{*}{$\begin{array}{l}\text { Chloroquine } \\
300 \mathrm{mg} \\
\text { single dose }\end{array}$} & Before treatment & 248 & 185 & 75 & 25 & 10 \\
\hline & after: I week & 222 & 5 & 2 & 0 & - \\
\hline & 2 weeks & 216 & 8 & 4 & 0 & - \\
\hline & 3 weeks & 223 & 21 & 9 & 0 & - \\
\hline & 4 weeks & 147 & 24 & 16 & 0 & - \\
\hline \multirow{5}{*}{$\begin{array}{l}\text { Untreated } \\
\text { controls }\end{array}$} & Before trial & 78 & 60 & 77 & 10 & 13 \\
\hline & after: 1 week & 89 & 61 & 69 & 11 & 12 \\
\hline & 2 weeks & 76 & 56 & 74 & 13 & 17 \\
\hline & 3 weeks & 81 & 62 & 76 & 7 & 9 \\
\hline & 4 weeks & 84 & 68 & 81 & 16 & 19 \\
\hline
\end{tabular}


Review of the early literature as well as more recent results show that sulfonamides possess a distinct antimalarial activity. However, when give alone, their action is less marked and slower than that of the antimalarials commonly used in the treatment of the acute attack. Combinations with pyrimethamine provide better results, even in cases of pyrimethamine and chloroquine resistance. rhis warrants further investigations in an attempt to develop a therapeutic agent suitable for the treatment of such resistant cases. It may also be possible with ail appropriate combination of pyrimethamine with a sulfonamide to achieve a satisfactory method for suppressive treatment both in areas with and without pyrimethamine resistance. Three main points must still be carefully studied: 1) the risk of developing malaria resistance against one or both of the components of the combination. 2) The risk of developing bacterial resistance to sulfonamides if these substances are used on a large scale in too low doses. It seems indeed that antimalarial effect with the combination of sufonamides + pyrimethamine can be obtained with doses of sulfonamides which are below those usually employed in bacterial diseases. Since the range of the ratios providing potentiation is rather large, only ratios of the combination sulfonamides: pyrimethamine should be chosen in which an ant bacterial :ulfonamidemia is guaranteed. 3) It goes without saying that, although both pyrimethamine and modern sulfonamides, when given by themselves, have proved tc possess a large margin of safety, long term administration of their combination should be careful studied from the point of view of possible side effects.

Substantial evidence has already been produced to show that the long acting sulfonamide Fanasil (Ro 4-4393) given once or once weekly possesses marked schizonticidal activity against $\mathbf{P}$. falciparum. Although its action is slower than that of 4-aminoquinolines, it may be useful as a second choice drug in semi-immune subjects for the therapy of falciparum malaria. Preliminary results show that, when combined with pyrimethamine. Fanasil is highly cffective in suppressing fever and asexual parasitemia due to P. falciparum. Single doses of $1 \mathrm{~g}$ Fanasil together with $50 \mathrm{mg}$ pyrimethamine seem to be adequate for the treatment of acute falciparum malaria in semi-immune patients. The onset of action of the combination is much more rapid than that of the single components. Weekly doses of $500 \mathrm{mg}$ Fanasil and $25 \mathrm{mg}$ pyrimethamine appear to provide satisfactory suppressive effects against $\mathrm{P}$. falciparum at least in East Africa. This combination is active on strains which do not respond satisfactorily to the standard doses of pyrimethamine and/or chloroquine and seems to have a satisfactory sporontocidal effect.

Preliminary results indicate that Fanasil alone cannot be recommended for use against the other human malaria parasites. The combination with pyrimethamine appears to be much more effective. East African strains of P. malariae seem to respond better to the combination than do Malayan strains of $\mathrm{P}$. vivax but further trials are required before definite assessment can be made.

Fanasil by itself has no gametocytocidal or sporontocidal action but seems to potentiate the effect of pyrimethamine at least on sporogony of $\mathrm{P}$. falciparum.

\section{REFERENCES}

1) AGUIRRE, M. \& JIMÉNEZ CASADO, M.: "Expérimentation clinique avec un nouveau sulfamide, le Ro 4-4393" (paper presented at the III Int. Congr. Chemotherapy, stuttgart, July 1963. Proceedings pp. 672-675. Thieme Verlag, Stuttgart, 1964) .

2) ALMEIDA, D.: "Notas sôbre os trabalhos realizados pela campanha de er. radicaçăo da malária, independentemente ou sob forma de convênio, a respeito do comportamento anômalo da cêpa de Plasmodium falciparum resistente aos antimaláricos usuais" (presented at the II Congr. of the Brazil. Soc. Trop. Med.. Goiânia. January 1966).

3) BARCLAY, C.A. et al.: "Terapêutica de la lepra con el preparado Ro .... 4-4393". La Semana Médica 72 : 303-309, 1965 .

4) BASU, P.C. et al.: "Treatment of human malaria by diaminodiphenyl-sulfone (DDS), singly and in combination with pyrimethamine. A preliminary study of their effects in $P$. vivax and $P$. falciparum infections in Rajasthan, India". Indian J. Malariol. 16: 157, 1962. 
5) BASU, P.C. et. al.: "Potentiation of activity of diaphenyl-sulfone and pyrimethamine against $P$. gallinaceum and. $P$. cynomolgi bastianelli". Bull. WHO 31: 699, 1964.

6) BISHOP, A.: "The action of 2:4-diamino-6, 7-diisopropylpteridine upon Plasmodium gallinaceum and its relation to other compounds which are pteroylglutamic acid antagonists". Parasitology 44: 450-464, 1954.

7) BISHOP, A.: "Drug resistance in protozoa". Biol. Rev. 34: 445, 1959.

8) BISHOP, A.: "Resistance to diaminodiphenylsulphone in Plasmodium gallinaceum". Parasitology 55: 407-414, 1965.

9) BRENER, Z.: Personal communication.

10) CHOPRA, R.N. \& DAS GUPTA, B.M.: "A note on the therapeutic efficiency of soluseptazine in simian malaria $P$. knowlesi). Indian med. Gaz. 73: $395,1938$.

11) CHOPRA. R.N. \& DAS GUPTA, B.M.: "M. \& B. 693 (2-sulphanilyl-aminopyridine) in ape malaria". Indian med. Gaz. 74: 201, 1939.

12) CHOPRA, R.N. et al.: "Prontosil in Indian strains of malaria". Indian med. Gaz. 74: 321, 1939.

13) CHOPRA, R.N. et al.: "M. \& B. 693 in Indian strains of malaria". Indian med. Gaz. 74: 658, 1939 .

14) CHOPRA, R.N. \& BASU, B.C.: "Studies on the effect of antimalarial drugs upon the infectivity of patients to mosquitoes. III. "Prontosii". J . mal. Inst. India 2: 153, 1939.

15) COATNEY, G.R. \& COOPER, W.C.: "The prophylactic effect of sulfadiazine and sulfaguanidine against mosquitoborne Plasmodium gallinaceum infection in the domestic fowl (preliminary report)". Publ. Hlth Rep., Wash. 59: 1455, 1944.

16) COATNEY, G.R. et al.: "Studies in human malaria. I. The protective action of sulfadiazine and sulfapyrazine against sporozoite-induced falciparum malaria". Amer. J. Hyg. 46: 84, 1947.

17) COATNEY, G.R. et al.: "Studies in human malaria. II. The suppressive action of sulfadiazine and sulfapyrazine against sporozoite-induced vivax malaria (St. Elizabeth strain)" Amer. J. Hyg. 46: 105, 1947.

18) COGGESHALL, L.T.: "Prophylactic and therapeutic effect of sulphonamide compounds in experimental malaria". Proc. Soc. exp. Biol., N. Y., 38: 768, 1938.

19) COGGESHAL, L.T.: "The cure of Plasmodium knowlesi malaria in rhesus monkeys with sulphanilamide and their susceptibility to reinfection" Amer. J. trop. Med. 18: 715, 1938.
20) COGGESHALL, L.T.: "The selective action of sulfanilamide on the parasites of experimental malaria in monkeys in vivo and in vitro": $J$. exp Med. 71: 13, 1940.

21) COGGESHALL, L.T.: "Infection of Anopheles quadrimaculatus with Plasmodium cynomolgi, a monkey malaria parasite, and with Plasmodium lophurae, an avian malaria parasite" Amer. J trop. Med. 21: 525, 1941

22) COGGESHALL, L.T. \& MAIER, J. "Determination of the activity of various drugs against the malaria parasite". J . infect. Dis 69 108, 1941

23) COGGESHALL, L.T. et al.: "The effectiveness of two new types of chemotherapeutic agents in malaria, sodium p, p'-diamino-diphenylsulfone N,N'-didextrosesulfonate (p r o m in) and 2-sulfanilamida pyrimidine (sulfadiazine)". J. Amer. med. Ass. 117: 1077. 1941

24) COGGESHALL, L.T. et al,: "Prophylactic and curative effects of certain sulfonamide compounds on exoerythrocytic stages in Plasmodium gallinaceum malaria”. Proc. Soc. exp. Biol. N.Y., 57: 286, 1944.

25) COTTIER, P. \& HALDEMANN, G.: "De l'emploi d'un sulfamidé (Ro 4-4393) à durée d'action nrolongée dans le traitement de la pyélonéphrite chronique". Rev. méd. Suisse Romande 84, N. ${ }^{\circ} 4,1964$.

26) COXON, R.V. \& HAYES, W.: "Investigation into efficacy of sulphadiazine in treatment of malaria" Trans. Roy. Sor. trop. Med. Hyg. 39: 196, 1945. 1945) .

27) CURD, F.H.S.: "The activity of drugs in the malaria of man, monkeys and birds". Ann. trop. Med. Parasit. 37: 115, 1943

28) DAVEY. D.G.: "The use of avian malaria for the discovery of drugs effective in the treatment and prevention of human malaria. I. Drugs for clinical treatment and clinical prophylaxis". Ann. Trop. Med. Parasit. 40: 52-73, 1946.

29) DAVEY, D.G.: "Chemotherapy of malaria. Part 1: Biological basis of testing methods", in: Schnitzer. R.J. \& Hawking, F.: "Experimental chemotherapy", vol. I. Academic Press, New York \& Londion. 1963.

30) DeGOWIN, R.L. \& POWELL, R.C.: "Drug-resistant falciparum malaria" $\mathrm{J}$ : Lab. \& Clin. Med. 64: 851, 1964.

31) nfAZ DF LEÓN. A. : "Primejros casos de paludismo tratados por un derivado de la sulfanilamida". Bol Ofic. sanit. pan-amer. 16: 1039, 1937.

32) DIAZ DE LEON, A.: "Las sulfanilamidas en el tratamiento del paludismo" Medicina Méx. 18: 89, 1938.

33) DIAZ DE LEON, A.: "El paludismo y su tratamiento intravenoso por las 
sulfanilamidas". Medicina Méx. 20: $551,1940$.

34) EYLES, D.E. \& COLEMAN, N.: "Synergistic effect of sulfadiazine and Daraprim against experimental toxoplasmosis in the mouse". Antibiotics \& Chemother. 8: 483, 1953.

35) FAGET, G.H. et al.: "Unsuccessful treatment of malaria with sulfonamide compounds". Publ. Health Rep., Wash. 53: 1364, 1938.

36) FAIRLEY, N.H. et al.: "Chemotherapeutic suppression and prophylaxis in malaria". Trans. Roy. Soc. trop. Med. Hyg. 38: 311, 1945.

37) FARINAUD, E. \& RAGIOT, C.: "Recherches sur l'emploi des dérivés de la sulfamide dans le traitement du paludisme". Bull. Soc. Path. exot. 31: 907,1938

38) FARINAUD, E. \& ELICHE, J.: “Nouvelles observations sur le traitement du paludisme par les dérivés de la sul. famide". Bull. Soc. Path. exot. 32: du paludisme par les dérivés de la su674,1939

39) FAUCON, R. et al.: "Etude de l'activité 'in vitro' sur Neisseria intracellularis et 'in vivo' dans la méningite cérébrospinale de la sulfanilamido-4-diméthoxy-5, 6-pyrimidine". Médecine Trop. 24, numéro spécial, 1964.

40) FERRARIS DE GASPARE, P.F. \& PENNA CAROPPI, $M$.: "Considérations sur l'emploi d'un nouveau sulfamide retard dans le traitement du trachome dans des régions hyperendémiaues". Rev. Int. Trachome 43: 132-136, 1966.

41) FINDLAY, G.M. et al.: "Investigations in the chemotherapy of malaria in West Africa. V. Sulphonamide compounds". Ann. trop. Med. Parasit. 40: 358,1946 .

42) FINDLAY, G.M.: "Recent advances in chemotherapy", vol. II. J. \& A. London Churchill Ldt., 1951.

43) FREIRE AMERICANO, S. \& PARAENSE, W.L.: "The prophylactic and curative action of sulfadiazine (2-sulfanilamide-pyrimidine), sulfapyridine (2-sulfanilamide-pyridine) and sulfanilamide (p-aminobenzo-sulfonamide) on erythro and exoerythrocytic cycles of 'Plasmodium gallinaecum'L Therapeutic and parasitological aspects)" Rev. Bras. Biol. 4: 27, 1944.

44) FRENKEL, J.K. \& JACOBS, L.: "Orular toxoplasmosis". A.M.A. Arch. Ophth. 69: 260-279, 1958.

45) GARDNER, W.A. \& DEXTER, L.: “A case of quartan malaria following transfusion and treated with sulfanilamde". J. Amer. med. Ass. 111: . 2473, 1938

46) GOODWIN, L.G. \& ROLLO, I.M. : In "Biochemistry and Physiology of Pro- tozoa" (S.H. Hutner and A. Lwoff, eds. vol. II, pp. 225-276. Academic Press, New York, 1955

47) GREENBERG, J : “The potentiation of the antimalarial activity of chlorguanide by p-aminobenzoic acid competitors". J . Pharmacol. 97: 238-242. 1949 .

48) GREENBERG, J.: "The antimalarial activity of 2, 4-diamino-6, 7-diphenylpterin; its potentiation by sulphadiazine and inhibition by pteroylglutamic acid'. J. Pharmacol, 97: 484-491, 1949 .

49) GREENBERG, J.: "The effect of analogues of folic acid on the activity of sulphadiazine against Plasmodium gailinaceum". Exptl. Parasitol. 3: 351-357, 1954

50) GREENBERG, J . \& RICHESON, E.M.: "Potentiation of the antimalarial activity of sulphadiazine by 2 , 4-diamino 5-aryloxypyrimidines". J. Pharmacol. 99: 444-4449, 1950

51) HALL, W.E.B.; "The sulphanilamides in tertian malaria". J. Pharmacol. 63: 353, 1938

52) HAFINASUTA, T. \& VIRAVAN, C.: "Sulphormethoxine (Fanasil) and combinations of sulphormethoxine (Fanasil) and chloroquine or pyrimethamine (Daraprim) in the treatment of chloroquine-resistant falcinarum malaria in Thailand" (presented at the llth Pacific Science Congress, Tokyo, August 1966).

531 HAWKING, F. \& THURSTON, J.P. "Chemotherapeutic and other studies on the pre-erythrocytic forms of simian malaria Plasmodium cynomolgi". Trans. Roy. Soc. Trop. Med Hyg. 46: 293-300, 1952

54) HAWKING, F.: Quoted by Goodwin. L.G. and Rollo, I.M. in: "The chemotherapy of malaria, piroplasmosis. trypanosomiasis, and leishmaniasis" Biochemistry and physiology of protozoa, vol. II, Academic Press, New York, 1955.

55) HAWKING, F.: "Chloroquine resistance in Plasmodium berghei". Amer. J . Trop. Med. Hyg. 15: 287-293, 1966.

56) HILL, R.A. \& GOODWIN, H.M., Jr. "'Prontosil' in treatment of malaria: report of 100 cases". Sth. med. J. Nashville, 30: 1170, 1937.

57) HILL, J.: "The schizonticidal effect of some antimalarials against Plasmodium berghei". Ann. Trop. Med. Parasitol. 44: 291-297, 1950

58) HILL, J.: "Chemotherapy of malaria Part 2: The antimalarial drugs", in: Schnitzer, R.J. \& Hawking, F.: "Experimental chemotherapy", vol. I Academic Press, New York \& London, 1963. 
59) HITCHNINGS, G.H.: "The use of an antmietabolite in the chemotherapy of malaria and other indications" Clin. Pharmacol. Therap. 1: 570, 1960.

60) HITCHINGS, G.H.: "The utilization of biochemical differences between host and parasite as a basis for chemotherapy' in: 'Drugs, Parasites and Hosts" (L.G. Goodwin \& R.H. Nimmo-Smith, eds.), p. 241. J. \& A. Churchill Ltd., London, 1962

61) HOLZ, J : : (Personal communication).

62) HURLY, M.G.D.: "Potentiation of pyrimethamine by sulphadiazine in human malaria". Trans. Roy. Soc. Trop. Med. Hyg. 53: 412, 1959.

63) JACOBS, R.L.: "Selection of strains of Plasmodium berghei resistant to quinine. chloroquine and pyrimethamine". J. Parasitol. 51: 481-482, 1965.

64. KAMINSKY, A. et al.: "Clinical experience with the long-acting sulfonamide Ro 4-4393 in dermatology". Paper presented at the III Int. Congr Chemotherapy, stuttgart, July 1963. Proceedings pp. 676-80, Thieme Verlag. Stuttgart, 1964.

65) KRISHNASWAMI, A.K. et al.: "Studies on Plasmodium berghei Vincke \& Lips, 1948. XV. Acquired resistance to sulphadiazine". Indian J. Malariol. 8: $9-18,1954$

66) LAING, A.B.G.: "Preliminary observations on drug-resistance to malaria in northern Tanzania". Ann. Rep. East Afr. Inst. Malaria \& Vector-Borne Diseases, 1963-64.

67) LAING, A.B.G.: "Antimalarial effect of sulphorthodimethoxine (Fanasil)" Brit. Med. J . 1964, 2, 1439-1440.

68) LAING, A.B.G.: "Treatment of acute falciparum malaria with sulphorthodimethoxine (Fanasil)". Brit. med. J . 1965, 1, 905-907.

69) LAING, A.B.G.: "Treatment of acute falciparum malaria with diaphenylsulfone in North-East Tanzania". J . Trop. Med. Hyg. 68: 251-253, 1965.

70) LAING, A.B.G.: "Sporogony in Plasmodium falciparum apparently unaffected by sulforthomidine (Fanasil)" Trans. Roy. Soc. Trop. Mep. Hyg 59: $357-8,1965$

71) LAING, A.B.G.: "The treatment of acute malaria with sulforthomidine and a combination of sulforthomidine and primethamine". Bull. WHC 34: 308-311, 1966

72) LAING, A.B.G.: Personal communication.

73) LAING, A.B.G.: Personal communication.

74) LOPES, FERREIRA C. et. al.: "Tratamento de micetoma por 'Nocardia brasiliensis' com uma nova sulfamida administrada uma vez por semana" Rev. Assoc. Med, Brasil. 11: 135-139, 1965
75) LOPES, P.F.A. \& RODRIGUES DA SILVA, J.: 'Resistência do Plasmodium falciparum aos quimioterápicos" Presented at the II Congr. of the Brazil. Soc. Trop. Med., Goiânia, January 1966

76) MAIER, J . \& RILEY, E.: "Inhibition of anitmalarial action of sulfonamides by p-aminobenzoic acid". Proc. Soc Expt1. Biol. Med. 50: 152-154, 1942.

77) MANWELL: R.D. et al.: "Effect of sulfanilamide and sulfapyridine on the avian malarias". Proc. Soc. exp Biol. N.Y., 46: 523, 1941.

78) MARSHALL, P.B. "The absorption of sulphonamides in the chick and the canary, and its relationship to anti. malarial activity", J. Pharmacol. 84: 1. 1945

79) MARSHALL, E.K., Jr., et. al.: "The antimalarial action in ducks of certain sulfanilamide derivatives". J. Pharmacol. 86: 2731946 .

80) McGREGOR, J.A. et al. : "Pyrimethamine and sulphadiazine in treatment of malaria". Brit. Med. J. 1963, 2 728 .

81) MENK, W. \& MOHR, W.: "Zur Frage der Wirksamkeit des Prontosils bej akuter Malaria". Arch. Schiffs u. Trovenhyg. 43: 117, 1939.

82) MUDROW-REICHENOW, L.: "Ueber die chemotherapeutische Beinflussbarkeit des Plasmodium berqhei Vincke und. Lips". Z. Tropenmed. u. Parasitol. 2: 471-485, 1951.

83) NIVEN, J.C.: "Sulphanilamide in the treatment of malaria". Trans. Roy. Soc. trop. Med. Hyg. 32: 413, 1938

84) PETERS, W.: "Drug resistance in Plasmolium berghei Vincke and Lips. 1948. I. Chloroquine resistance". Explt. Parasitol. 17: 80-89, 1965.

85) PETERS, W.: "Drug resistance in Plasmodium berghei Vincke and Lip;, 1948. II. Triazne resistance". Exptl. Parasitol. 17: 90-96, 1965

86) PETERS, W.: "Drug resistance in Plasmodium berahei Vincke and Lips. 1948. III. Multiple drug resistance" Expt1. Parasitol. 17: 97-102, 1965.

87) PETERS, W.: "Drug responses of mepracine- and primaquine-resistant strains of Plasmodium berghei Vincke and Lips 1948". Ann. Trop. Med. Parasitol. 60: 25-30, 1966.

88) PETERS, W.: "Drgu resistance and cross-resistance in Plasmodium berghei" (presented at the III Int. Pharmarological Congr., July 1966, São Paulo) .

89) PRINGLE, G. \& LANE, F.C.T.: "Notes on the clearance of malaria parasitaemias among children undergoing a comparative trial of repository anti. malarial agents, by the sulphonamide sulphorthomidine (Fanasil, Ro 4-4393), and by diaphenylsuifone (DDS)" (presented at the Symposium 
90) RAMAKRISHNAN, S.P. et al.: "Stutious Dis., Munich, April 1966). on Fanasil; IV Int. Congr. for Infecdies on the toxicity and action of diaminodiphenyl-sulfone (DDS) in avian and simian malaria". Bull. WHO 27: 213-221, 1962.

91) RAMAKRISHNAN, S.P. et. al.: "A study on the joint action of diaminodiphenyl-sulphone (DDS) and pyrimethamine in the sporogony cycle of Plasmodium gallinaceum: Potentiation of the sporontocidal acitvity of pyrimethamine by DDS". Indian $\mathrm{J}$. Malariol. 17: 141-148, 1963.

92) RAY, A.P. \& NAIR, C.P.: "Studies on Nuri strain of $P$. knowiesi. Fart IX. Susceptibility to sulphonamide substituted dihydrotriazine, sulphadiazine and mepracine". Indian $\mathrm{J}$. Malariol. 9: 196-202, 1955.

93) READ, H. \& PINO, J.O.: "Versuche mit den Sulfonamid-Präparaten bei der Malariabehandlung". A r c h . Schiffs- u. Tropenhyg. 42: 132, 1938 .

94) RICHARDS, W.H.G.: Personal communication (in press).

95) RICHARDSON, A.P. et al.: "Chemotherapy of Plasmodium knowles infections in Macaca mulatta monkeys" J. Pharmacol. 87: 203, 1946.

96) RIEDER, J. \& BOEHNI, E.: "Vergleichende Untersuchungen über die chemotherapeutisch wirksamen Plasmaspiegel langwirkender Sulfanilamide bei künstlich infizierten Versuchstieren". Presented at the III Int. Congr. Chemotherapy, Stuttgart, July 1963. Proceedings pp. 622-626, Thieme Verlag, Stuttgart, 1964.

97) ROBERTSON, G.I. et al.: "Cross-resistance between Daraprim and Proguanil". Brit. Med. J. 1952, 2, ..... 1255-1256; correspondence.

98) ROLLO, I.M.: "A 2: 4-diamino-pyrimidine in the treatment of proguanilresistant laboratory malaria strains:" ature 168: 332-233, 1951.

99) ROLLO, I.M.: "Daraprim resistance in experimental malarial infections" Nature 170: 415, 1952

100) ROLLO, I.M.: "Daraprim - experimental chemotherapy". Trans. Roy. Soc. Trop. Med. Hyg. 46: 474-484, 1952.

101) ROLLO, I.M.: "The mode of action of sulphonamides, proguanil and pyrimethamine on Plasmodum gallinaceum" Brit. J. Pharmacol. 10: 208-214, 1955.

102) ROLLO, I.M.: "The chemotherapy of malaria", in: "Biochemictry and Physiology of Protozoa" (S.H. Hutner, ed.), vol. III. Academic Press, New York \& Londion, 1964

103) ROSSAN, R.N.: "The effect of antimalarial drugs on the exoerythrocytic and erythrocytic stages of blood- incuced infections of Plasmodium fallax in the turkey". Explt. Parasitol. 6: 163-188 1957.

104) SCHMIDT, L.H. et al.: "Development of resistance to chlorguanide (paludrine) during treatment of infections with Plasmodium cynomolgi". $\mathbf{J}$. Pharmacol. 95: 382-398, 1949.

105) SCHMIDT, L.H. \& GENTHER, C.S.: "The antimalarial properties of 2, 4diamino-5-p-chlorophenyl-6-ethylpyrimidine (Daraprim)". J. Pharmacol. Exptl. Therap. 107: 61-91, 1953.

106) SCHNEIDER, J . \& CARUANA, M.: "Essais de traitement curatif du paludisme par la sulfaméthyldiazine (sumédine". Bull. Soc. Path. exot. 41: 478, 1948.

107) SCHNITZER, R.J . \& GRUNBERG, E.: "Drug-resistance of micro-organisms" Academic Press, New York, 1957.

108) SCHNITZER, R.J. "Drug resistance in protozoa". Inter. Rev. Trop. Med. 2: 239-266, 1962.

109) SCHNITZER, R.J.: "Drug resistance of pathogenic protozoa".. Presented at the N.Y. Acad. Sci., April, 22, 1966.

110). SHUTE, G.T. \& DOWLING, M.A.C.: "Effect of sulphorthodimethoxine on parasites of Plasmodium falciparum and Plasmodium malariae on semiimmune schoolchildren in the Western region of Nigeria". Unpublished WHO document WHO/Mal/66.544.

111) RODRIGUES DA SILVA, J .: Personal communication.

112) SINGH, J. et al.: "Screening of antimalarials against $P$. gaílnaceum in chicks. Part I. Preliminary studies" Indian J. Malariol. 6: 145-158 1952.

113 ) SINGH, J. et. al.: "Acquired resistance to proguanil in Plasmodium knowlesi". Transc. Roy. Soc. Trop. Mep. Hyg. 46: 639-649, 1952).

114) SINGH, J . et al.: "Development of resistance to pyrimethamine in $P$. cynomolgi". Indian J. Malariol. 7: 357-369, 1953 .

115) SINGH, J. et. al.: Studies on Nuri strain of $P$. knowlesi. V. Acquired resistance to pyrimethamine". Indian J. Malariol. 8: 187-195, 1954.

116) STNGH. J ot. al.: "Therapeutic effect of sulphadiazine and dihydrotriaz nts agusst bos:-induced. $P$. cyncmo'ogi infection". Indian J. Malariol. 10: 131-135, 1956.

117) SINTON, J.A. et al "Some sucessful trials of proseptasine as a true causal prophylactic against infection with Plasmoxium falciparum". Ann. trop. Med. Parasit. 33: 37, 1939.

118) SORLEY, E.R. \& CURRIE, J.G.: "Notes on the experimental use of prontosil album in the treatment of malaria". J.R. nav. med. Serv. 24: 322, 1938 . 
119) TAYLOR, D.J. \& GREENBERG, J.: "Hyperactivity of metachloridine against Plasmodium gallinaceum in chicks maintained on a purified diet" Proc. Soc. Exptl. Biol. Med. 90: .. 551-554, 1955.

120) THOMPSON, P.E. et al.: "Quinineresistant Plasmodium berghei in mice". Science 148: 1240-1241, 1965.

121) THOMPSON, P.E. et. al.: "Studies on a dihydrotriazine and a sulfone alone and in combination against Plasmodium berghei in mice". Amer. J. Trop. Med. Hyg. 14: 198-206, 1965.

122) THOMPSON, P.E.: Drug resistance in malaria and criteria in the selection of new agents for trial against drugresistant strains". Presented at the III Int. Pharmacol. Congr., São Paulo, July 1966 .

123) THOMPSON, P.E.: Personal communication

124) THURSTON. J.P.: "The action of antimalarial drugs in mice infected with Plasmodium berghei". Brit. J. Pharmacol. 5: 409-416, 1956.

125) THURSTON, J.P.: "The action of dyes, antibiotics, and some miscellaneous compounds against Plasmodium berghei"'s Brit. J. Pharmacol. 8: ... 162-165. 1953 .

126) THURSTON, J.P. "The chemotherapy of Plasmodium bergheiL I. Resistance to drugs". Parasitology 43: 246-252, . 1953.

127) THURSTON, J.P.: “The chemotherapy of Plasmodium berghei. II. Antagonism of the action of drugs". Parasitology 44: $99-110,1954$.

128) TSCHUDI-MADSEN, S.: "Serum concentration and antibacterial activity of 4-sulfanilamido-5, 6-dimethoxypyrimidine". Amer. J. Mel. Sci. 247: 127, 1964

129) VAN DER WIELEN, Y.: "Prontosil en malaria quartana". Ned. Tijdschr. Geneesk, 81: 2905, 1937.

130) VASINA, S.G.: "Testing of chemotherapeutic agents against tissue forms of Plasmodium gallinaceum in chick embryos" (Med. Parasitol. Parasitic Diseases, U.S.S.R., 25: 327-330. 1956. Seen in Top. Dis. Bull. 54: 537-538, 1957.

131) WILLIAMSON, J. \& LOÚRIE, E.M.: 'Acquired paludrine-resistance in Plasmodium gallinaceum. I. Development of resistance to paludrine and failure to develop resistance to certain other antimalarials". Ann. Trop. Med. Parasitol. 41: 278-291, 1947.

132) WISELOGLE, F.Y.: "A survey of antimalarial drugs, 1941-45". 2 vols. $J$. W. Edwards, Ann Arbor, Michigan,.. 1946. 